\title{
THE TIP OF THE ICEBERG: A SURVEY OF THE PHILOSOPHY AND PRACTICE OF CANADIAN PROVINCIAL AND TERRITORIAL JUDGES CONCERNING JUDICIAL DISQUALIFICATION
}

\author{
PHILIP BRYDEN* AND JULA HUGHES**
}

The "reasonable apprehension of bias" test for judicial disqualification has been a fixture in the common law world for centuries; despite this settled state of the law, judges and commentators have been concerned that the application of the test might be contentious in a significant number of cases. In this article, the authors report on an empirical study surveying Canadian provincial and territorial judges on common scenarios which raise the possibility of recusal. Situated in the applicable case law, the findings demonstrate a wide divergence of opinion on substance and procedure among respondents in their attitudes toward recusal in situations that are analytically marginal, but not rare. The article concludes with some possible explanations for the divergence.
Le critère de "crainte raisonnable de partialité » pour disqualification judiciaire fait partie de la common law depuis des siècles. Malgré cet état de choses bien établi dans le droit, les juges et les commentateurs s'inquiètent que l'application du critère pourrait être controversée dans un nombre important de causes. Les auteurs de cet article réfèrent à une étude concrète sur les juges provinciaux et territoriaux canadiens relativement à des scénarios ordinaires soulevant la possibilité de disqualification. Les conclusions, qui font partie de la jurisprudence en vigueur, démontrent une grande divergence d'opinions en matière de fondement et de procédure parmi les répondants dans leurs attitudes à l'égard de la disqualification dans les situations marginales, quoique pas rares, sur le plan analytique. L'article conclut avec quelques explications sur cette divergence.

\section{TABLE OF CONTENTS}

I. INTRODUCTION ................................ 570

II. THE DEVELOPMENT AND ADMINISTRATION

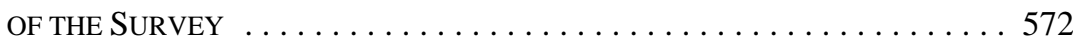

III. THE PARTICIPANTS . . . . . . . . . . . . . . . . . . . . . . . . . . . . . . 574

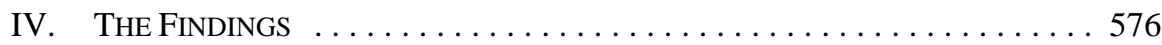

A. HOW OFTEN DO THE PARTICIPANTS

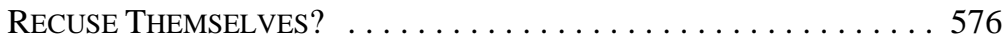

B. DOES THE "ReASONABLE APPREHENSION OF Bias"

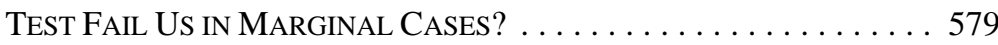

C. HOW Did THE PARTICIPANTS RESPOND TO

DifFERENT RECUSAL SCENARIOS? . . . . . . . . . . . . . . 583

D. ARE THERE EXPLANATIONS FOR DiFFERENT

RESPONSES TO RECUSAL SCENARIOS? . . . . . . . . . . . . . . . . . . . 596

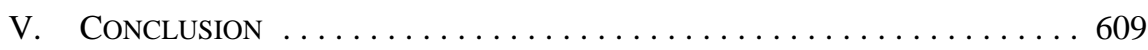

APPENDIX: SURVEY OF CANADIAN PROVINCIAL AND

TERRITORIAL JUdGES CONCERNING JUdiCIAL RECUSAL . . . . . . . 610

** Wilbur Fee Bowker Professor and Dean, Faculty of Law, University of Alberta.

Associate Professor, Faculty of Law, University of New Brunswick. 


\section{INTRODUCTION}

To an outside observer, it may seem strange that anyone would be interested in conducting an empirical study of the practices and attitudes of Canadian provincial and territorial court judges toward judicial disqualification. The "reasonable apprehension of bias" test for judicial disqualification has been a fixture in the common law world for centuries, ${ }^{1}$ and the test itself is surely familiar to Canadian lawyers and judges. Nevertheless, our experience, both in reviewing the case law governing judicial disqualification and in conducting judicial education seminars about this topic with judges from across the country, led us to believe that the application of the test in practice might be more difficult than the outside observer might imagine.

In an article entitled “Legal Principles Governing the Disqualification of Judges,” Philip Bryden argued "that the conceptual tools we use in addressing issues of judicial impartiality tend to fail us precisely in the marginal cases where reasonable people could disagree on whether or not a judge ought to be disqualified.”2 Bryden took this view because he believed that, while the jurisprudence was helpful in identifying broad categories of cases in which a reasonable apprehension of bias might be a concern, within those categories it can be exceedingly difficult to determine the precise boundaries that differentiate situations which give rise to a reasonable apprehension of bias from those that do not.

In its 2003 decision in Wewaykum Indian Band v. Canada, the Supreme Court of Canada observed that the application of the reasonable apprehension of bias test is "highly factspecific.”3 In the Court's words:

Whether the facts, as established, point to financial or personal interest of the decision-maker; present or past link with a party, counsel or judge; earlier participation or knowledge of the litigation; or expression of views and activities, they must be addressed carefully in light of the entire context. There are no shortcuts. ${ }^{4}$

While courts often attempt to explain the results of this contextual analysis with reference to the presumed knowledge or attitudes of the reasonable person, ${ }^{5}$ in many instances it cannot help but appear that the sensibilities of the judge making the determination play a very significant role, at least in marginal cases.

If this observation is correct, then it is a matter of more than passing interest to determine whether judges have a shared understanding of how marginal cases should be decided. A reasonably robust collective sense of when judges should and should not recuse themselves in marginal cases would provide comfort, both to judges and to parties to litigation, that the

See Dr. Bonham's Case (1610), 8 Co. Rep. 113b, 77 E.R. 646; Dimes v. Proprietors of the Grand Junction Canal (1852), 3 H.L. Cas. 759, 10 E.R. 301 (H.L.); Committee for Justice and Liberty v. National Energy Board (1976), [1978] 1 S.C.R. 369 [Committee for Justice].

2 Philip Bryden, "Legal Principles Governing the Disqualification of Judges” (2003) 82 Can. Bar Rev. 555 at 557.

2003 SCC 45, [2003] 2 S.C.R. 259 at para. 77 [Wewaykum].

Ibid.

See e.g. R. v. S.(R.D.), [1997] 3 S.C.R. 484 at paras. 48-49, L’Heureux-Dubé and McLachlin JJ.; Taylor v. Lawrence, [2002] EWCA Civ 901, [2003] Q.B. 528 at paras. 61-63, Lord Woolf C.J. [Taylor]; Saxmere Company Limited Ltd. v. Wool Board Disestablishment Company Limited (No. 1), [2009] NZSC 72, [2010] 1 N.Z.L.R. 35 at paras. 5-8, Blanchard J.; para. 38, Tipping J.; and paras. 95-99, McGrath J. [Saxmere (No. 1)]. 
reasonable apprehension of bias test can be applied reasonably consistently. This is important not only for the usual reason that consistency in the application of the law is desirable, but also because an incorrect judicial determination that it is appropriate to sit tends to have negative consequences for confidence in the administration of justice and for the professional reputation of the judge.

One possible implication of the negative consequence for a judge's professional reputation might be a tendency on the part of some judges to be overly cautious in assessing whether it is appropriate to sit. This not only shifts the burden of the adjudication of cases onto other judges and, in some instances, creates delay and inconvenience for parties, but also puts subtle pressure on the boundaries of when it is appropriate to sit in a marginal case. This is because, in the absence of clear authority that a particular fact situation does not give rise to a reasonable apprehension of bias, it would be more than a little uncomfortable for a judge to take the position that it is appropriate to sit if it were apparent that a number of his or her judicial colleagues took a contrary view.

It seemed to us that it might be useful to look beyond the reported decisions and to inquire into the experience that judges have with recusal. In addition, we thought that it would be useful to explore judicial attitudes to disqualification in situations that seemed to us to be reasonably common, but analytically marginal. The term "analytically marginal” describes situations where, based on the jurisprudence and/or policy, plausible arguments could be advanced for suggesting both that a judge should and should not recuse. In part, we were interested in conducting this type of study because we suspected that the reported cases might not reflect the entirety, or perhaps not even the majority, of judicial experience with situations in which there might be reason to doubt whether it was appropriate for the judge to sit. In particular, we believed that in many situations judges were simply recusing themselves without providing written reasons for doing so and that, in others, judges decided that it was not necessary to disclose to parties facts that might cause a party to consider whether to ask the judge to recuse himself or herself.

More fundamentally, we were interested in exploring judicial experience and attitudes concerning disqualification because we suspected that the jurisprudence did not offer a great deal of guidance to judges in some of these marginal situations. We thought that it would be useful for judges from across the country to learn more about the extent to which they did, or did not, share a common understanding of how to address these situations. If there were areas of disagreement it would be useful if we could identify factors that might at least partly explain the reasons for this disagreement. We had some hypotheses about what some of these explanations might be, as did many of the judges with whom we discussed our ideas, but we needed an opportunity to test our theories by asking Canadian judges to share their views with us in a less anecdotal format. Ultimately, we were hoping that the study would identify particularly contentious or difficult situations and provide a basis for the development of improved analytical frameworks for resolving these situations. 
We were pleased to discover that the leadership of the Canadian Association of Provincial Court Judges (CAPCJ) ${ }^{6}$ shared our interest in this subject and was willing to assist us in our efforts to find out more about the actual experience and thinking of judges about judicial disqualification. In particular, we were extremely fortunate to have engaged the interest of Judge David Orr of the Provincial Court of Newfoundland and Labrador, who is the Chair of the CAPCJ's Committee on the Law. With Orr J.'s support, in 2007 we approached the CAPCJ's President at the time, Judge Irwin Lampert of the Provincial Court of New Brunswick, who secured the approval of the organization's Executive Committee to cooperate with a survey that we proposed to conduct exploring these issues. Judge Orr assembled a group of interested judges from across the country to assist us with the design of the survey, and other judges helped at various points to distribute the questionnaire. ${ }^{7}$ We gave a presentation of our preliminary findings to the CAPCJ's Executive Committee at the organization's 2008 Annual Conference in Quebec City. We benefited from many useful comments as a result of that presentation, and we presented a final report of our findings to the Executive Committee at the CAPCJ's 2009 Annual Conference in Calgary. It would not have been possible for us to do this work without the co-operation and encouragement of the CAPCJ as an organization, and of these judges in particular. We are extremely grateful for this assistance, and we wish to thank everyone who gave their time and knowledge to help make this work more valuable to judges. As much as we appreciate this assistance, we should note that we are ultimately responsible for the survey and the analysis of our results.

\section{ThE DEVELOPMENT AND AdMINISTRATION OF THE SURVEY}

The questionnaire was developed in consultation with a working group of provincial court judges. ${ }^{8}$ The working group identified situations that met two criteria for what we would later describe as analytically marginal situations: they seemed to arise reasonably frequently in their jurisdictions, and they appeared to be either difficult to resolve or were the source of disagreement among provincial court judges. Members of the working group consulted with colleagues in their own jurisdictions to identify further scenarios that might be of interest. The survey scenarios were based on situations developed through the working group process. Additionally, we drafted introductory questions designed to elicit demographic data. Following expert review of the draft survey instrument and approval of the project by the Research Ethics Board of the University of New Brunswick, the questionnaire, consent form, and instructions were translated into French.

The CAPCJ is a federation of provincial and territorial judges' associations and has a membership of over 1,000. For more information, the CAPCJ is online: CAPCJ <http://www.judges-juges.ca/>.

The committee of judges who assisted with the design of the survey included Judge Colin Flynn of the Provincial Court of Newfoundland and Labrador, Judge Barbara Beach of the Provincial Court of Nova Scotia, Judge Ronald LeBlanc of the Provincial Court of New Brunswick, Judge Richard LaFlamme of the Court of Quebec, Judge Judith Elliott of the Provincial Court of Manitoba, Chief Judge Carol Snell of the Provincial Court of Saskatchewan, and Judge Gurmail Gill of the Provincial Court of British Columbia. Other judges who gave us valuable assistance included Judge Jean Paul Decoste of the Court of Quebec; Justices Sharman Bondy, Russell Otter, and David Stone of the Ontario Court of Justice; and Lampert J.'s successor as the CAPCJ's President, Judge Therese Alexander of the Provincial Court of British Columbia.

We are grateful to Orr J. for assembling and guiding the working group, to Dr. Elizabeth Sloat of the University of New Brunswick for her review of the survey instrument and her expert advice on survey methodology, to Dr. Bernd Kurz, then Chair of the Research Ethics Board of the University of New Brunswick for his advice on issues of voluntariness, confidentiality, consent records, and the secure storage of survey data, and to the CAPCJ for making a French translation of the survey and attendant documentation available to participants. 
The instructions to the questionnaire informed participants that we were conducting the survey with the co-operation of the CAPCJ, but that we were ultimately responsible for the survey and the distribution of our findings. They were also assured that their individual answers were confidential and would not be reported in a way that might lead to the identification of any individual judge with a particular answer. Finally, participants were informed that their participation was completely voluntary and that they could decline to answer any particular question.

The questionnaire is in two parts. The first part consists of 15 introductory questions: seven of which ask for background information about where the participants sit and the types of jurisdiction they exercise, four of which ask participants about their personal experience with recusal, and four of which ask about general expectations with respect to recusal in the participant's jurisdiction.

The second and longer part of the questionnaire consists of 32 scenarios that raise questions about whether recusal would be appropriate. We grouped the scenarios into three categories: (1) professional relationships (five scenarios), (2) social relationships (six scenarios), and (3) prior knowledge derived from other judicial proceedings (21 scenarios). We further subdivided the "prior knowledge" group into three sub-categories: (a) bail hearings (four scenarios), (b) subsequent or multiple trials (nine scenarios), and (c) subsequent related proceedings (eight scenarios). For each scenario we asked the participants to answer three questions: (1) would they consult a colleague before deciding whether to recuse themselves, (2) would they inform the parties before deciding whether to recuse themselves, and (3) what their ultimate decision would be if faced with this particular situation. We offered four options to the participants in answering the third question: (a) definitely recuse yourself, (b) uncertain, (c) recuse yourself if a party objects, and (d) definitely not recuse yourself. We also gave participants an opportunity to identify factors that might have altered their answers to various questions.

The survey was administered in four different settings. The survey was initially distributed to judges who attended the CAPCJ's 2007 Annual Conference in Vancouver. ${ }^{9}$ This produced the largest number of responses and the broadest distribution of participants from across the country, but we decided to resample in some key geographic areas in order to expand the overall size of the sample and increase the number of responses from judges in central and eastern Canada. The survey was circulated at the Nova Scotia Provincial Court's judicial education seminar held in the fall of $2007,{ }^{10}$ as a result of which provincial court judges in Nova Scotia (along with Prince Edward Island) had the highest rate of response of any province. The rate of response from judges in Quebec and Ontario was still relatively low, so we received the assistance of judges in these provinces who agreed to circulate the survey to judges in their own areas. ${ }^{11}$

We would like to thank Decoste J., who assisted us by distributing the survey to a number of judges of the Court of Quebec who sit in the eastern part of that province, and Otter and Stone JJ., who distributed the survey to judges of the Ontario Court of Justice who sit in the greater Toronto area. 


\section{The Participants}

All survey participants are Canadian provincial or territorial judges. Altogether the four distributions of the survey produced 137 responses. The participants included judges from every Canadian province and one territorial judge, as well as two judges who sit in more than one jurisdiction. Since there were approximately 1,037 provincial and territorial judges sitting in Canada at the time of the initial distribution of the survey, ${ }^{12}$ roughly 13 percent of the judges from across the country took part in the survey. The geographic distribution of the participants is set out in Table 1, below.

Most of the judges who participated in the survey were relatively experienced judges. A majority (54 percent) had been serving on the bench for more than ten years, and a further 15 percent had been judges for between six and ten years. On the other hand, 32 percent were in the first five years of their appointments, so we believe that we had a reasonable sample of relatively new appointees, as well as more experienced judges.

The majority of respondents (56 percent) sat in larger urban centres. They indicated that they presided over the majority of their cases in communities of over 100,000 people, while 20 percent stated that they sat mainly in mid-sized communities $(25,000-100,000)$, and 24 percent sat mainly in communities of less than 25,000 people.

This distribution seemed to represent a reasonable approximation of the actual distribution of provincial court judges across the country. According to Statistics Canada, census metropolitan areas are communities with an urban core population of at least 100,000 people. ${ }^{13}$ In the 2006 census there were 33 census metropolitan areas in Canada and they accounted for 68 percent of Canada's population. ${ }^{14}$ If we assume that the distribution of judges lags somewhat behind the growth of population in major urban centres, it would make sense that the percentage of Canadian provincial court judges sitting primarily in census metropolitan areas would be somewhere in the 50-60 percent range.

More importantly, the breakdown of responses meant that there were reasonably high numbers of judges who sit primarily in larger urban centres and judges who sit mainly in smaller communities. This division allowed us to test certain hypotheses we had developed about the significance of the size of the community in which a judge worked for his or her attitudes towards recusal.

Finally, we asked the judges what type of subject matter jurisdiction they exercised. Almost all of the participants in the survey (96 percent) exercised at least some criminal

We attempted to ascertain the number of Canadian provincial and territorial judges in the summer of 2007, just prior to the initial administration of the survey, by contacting courts directly. Some jurisdictions did not provide us with this data and in these cases we determined the number of judges by reviewing the lists of judges identified on the websites of the Canadian provincial and territorial courts in the summer of 2009. Obviously the number of judges in each jurisdiction will vary from time to time as judges retire or new judges are appointed, but this is a sufficiently close approximation for the purposes of our study.

13 Government of Canada, “Tables by metropolitan area,” online: Statistics Canada <http://www40.stat can.gc.ca/z01/cs0007-eng.htm>.

14 Government of Canada, “Census Snapshot of Canada - Urbanization,” online: Statistics Canada <http://www.stats.can.gc.ca/pub/11-0008-x/2007004/10313-eng.htm>. 
jurisdiction. Half of the judges (50 percent) responded that they exercised a mix of criminal, family, and small claims jurisdiction, and 46 percent indicated that they exercised only criminal jurisdiction. A relatively small percentage of participants exercised only small claims jurisdiction (3 percent) or only family jurisdiction (2 percent). On the other hand, 9 percent of the respondents indicated that a significant portion of their work was devoted to a court that had specialized jurisdiction, such as a drug court or a mental health court.

Overall we were satisfied with the number of judges who participated in the survey, and we believe that they represent a reasonable cross-section of Canadian provincial court judges. As is the case with all voluntary surveys, reporting biases are possible and resampling may have had some limited effect on the results. It is, therefore, important not to exaggerate the precision of the survey results. Despite this, we are confident that the survey has provided meaningful answers.

It should further be noted that it was relatively unusual for participants to answer every question, though different individuals left out different questions. The questions that were often bypassed invited judges to consider scenarios involving particular types of criminal or civil jurisdiction, and we suspect that in many instances judges did not respond to these scenarios because they did not have personal experience with the exercise of this type of jurisdiction. For ease of reference, unless otherwise noted, we have chosen to report the results in terms of the percentage of participants who actually answered any particular question rather than the percentage of individuals who took part in the survey as a whole. In the tables setting out the responses to the various scenarios, however, we set out numbers as well as percentages of judges who provided particular answers.

Using our database it is possible to break down the sample into smaller populations (for example, by province), but as one does so questions about the size and representativeness of the sample need more careful analysis. For the purposes of this article, therefore, we concentrated on the national picture and focused our analysis of potential differences between sub-populations on the size of community in which the participants presided over the majority of their cases. In the future it would be interesting to use the same data set to explore whether there are regional or other variations in experience with or attitudes toward different recusal scenarios. 
TABle 1 - SurVey PARTiCipants ${ }^{15}$

\begin{tabular}{|l|c|c|c|c|}
\hline Jurisdiction & Participants & $\begin{array}{l}\text { Judges in } \\
\text { Jurisdiction }\end{array}$ & $\begin{array}{l}\text { \% of Judges in } \\
\text { Jurisdiction who } \\
\text { Participated }\end{array}$ & $\begin{array}{l}\text { \% of Survey } \\
\text { Participants from } \\
\text { this Jurisdiction }\end{array}$ \\
\hline $\begin{array}{l}\text { Newfoundland and } \\
\text { Labrador* }\end{array}$ & 9 & 24 & 37 & 7 \\
\hline Nova Scotia** & 22 & 33 & 67 & 16 \\
\hline $\begin{array}{l}\text { Prince Edward } \\
\text { Island** }\end{array}$ & 2 & 3 & 67 & 1 \\
\hline New Brunswick* & 2 & 31 & 6 & 1 \\
\hline Quebec* & 16 & 270 & 6 & 12 \\
\hline Ontario* & 33 & 281 & 12 & 24 \\
\hline Manitoba* & 4 & 37 & 11 & 12 \\
\hline Saskatchewan** & 17 & 48 & 35 & 10 \\
\hline Alberta** & 14 & 147 & 10 & 11 \\
\hline British Columbia* & 15 & 151 & 10 & 2 \\
\hline Territories** & 1 & 12 & 8 & $\mathbf{1 0 0}$ \\
\hline $\begin{array}{l}\text { More Than One } \\
\text { Jurisdiction }\end{array}$ & 2 & N/A & N/A & \\
\hline TOTAL & $\mathbf{1 3 7}$ & $\mathbf{1 , 0 3 7}$ & $\mathbf{1 3}$ & \\
\hline
\end{tabular}

\section{THE FINDINGS}

\section{A. How Often do the Participants Recuse Themselves?}

The responses to our survey suggest that it is relatively common for Canadian provincial and territorial court judges to address the issue of recusal. Only 14 percent of the 132 participants who responded to the question "How often do you recuse yourself in a typical year?” indicated that they would not recuse themselves at all in a typical year. Two-thirds of the respondents (67 percent) indicated that they would recuse themselves between one and five times in a typical year. Moreover, 8 percent responded that they recused themselves between five and nine times in a typical year, and 11 percent reported that they recused themselves more than nine times in a typical year. 
insert Chart 1

It appears, as well, that the most common practice when judges recuse themselves is for them to do so of their own motion. When asked the question "In what percentage of these cases do you recuse yourself of your own motion rather than because a party objects," 55 percent of the respondents indicated that they recused themselves of their own motion more than 90 percent of the time. Another 30 percent stated that they recused themselves of their own motion between 50 percent and 90 percent of the time. Only 12 percent indicated that they never recused themselves of their own motion, and a further 2 percent answered that they recused themselves of their own motion less than 50 percent of the time.

Insert Chart 2 
We were also interested in finding out how often judges consult judicial colleagues before deciding whether to recuse themselves or not. As a general rule the answer was: not very often. Only 2 percent of respondents indicated that they "always" consulted colleagues before deciding to recuse themselves, although a further 25 percent stated that they "usually" sought the advice of colleagues. At the other end of the scale, 16 percent of respondents answered that they "never" consult colleagues before deciding whether to recuse themselves, and a further 29 percent indicated that they did so only "rarely." The final 29 percent answered that they engaged in consultation "sometimes.”

Insert Chart 3

Overall, the responses we received indicate that most Canadian provincial and territorial court judges will recuse themselves more than once, but less than five times in a typical year, and that normally they will recuse themselves of their own motion without consulting a judicial colleague before doing so. It is worth emphasizing, however, that there is a continuum of experience with recusal and that a quarter of the participants found themselves at opposite ends of the spectrum, with 14 percent not recusing themselves at all in a typical year and 11 percent indicating that they would do so ten or more times in a typical year. It is likely, of course, that this difference in experience is explained at least in part by the different situations in which judges find themselves, and that the different types of personal lives led by judges and the differences in their professional experiences prior to their judicial appointments will make some judges more likely than others to encounter situations in which they must recuse themselves. On the other hand, the degree of difference in experience with recusal that we detected is sufficiently large to suggest that at least part of the difference may be explained by different degrees of judicial sensitivity in applying the reasonable apprehension of bias test. We will explore this possibility in the balance of this article. 


\section{B. Does the “REasonable Apprehension of Bias” Test FAIL US IN MARGINAL CASES?}

As we noted in our introduction, we were particularly interested in learning whether the judges we surveyed had a shared understanding of how to resolve the types of marginal cases that we placed before them. As a result of our survey we discovered that there was not a strong consensus among the participants on how to address the 32 scenarios we posed. In fact there was, overall, considerable variability in the responses we received to the 32 scenarios. It is worth recalling that there were four possible responses to each scenario: (1) definitely recuse yourself, (2) uncertain, (3) recuse yourself if a party objects, and (4) definitely not recuse yourself. ${ }^{16}$ In only one of the 32 scenarios was there near universal agreement (more than 90 percent) on a single answer. In another five scenarios there was clearly a dominant view, with 65-89 percent of the participants agreeing on a single answer. The responses to eight scenarios revealed what we would describe as a "majority view," where more than 50 percent but less than 65 percent of the respondents selected the same response. On the other hand, in more than half of the scenarios there was no answer that attracted the support of a majority of the participants who answered that question. In 11 scenarios the most popular response attracted the support of $40-50$ percent of the participants who answered the question, and in seven scenarios no single answer garnered the support of as many as 40 percent of the respondents.

Using this measure, the scenarios dealing with "professional relationships" attracted the highest level of disagreement. Only one of the five professional relationship scenarios produced a bare majority view, and in the other four between 40 and 46 percent of the respondents to the question agreed on the most popular answer. As we will explain in more detail below, there appears to be a distinct difference between the attitudes of judges who sit primarily in communities of less than 25,000 and those who sit primarily in communities of more than 100,000 with respect to the judge's previous professional relationships as a basis for recusal. On the other hand, scenarios based on "prior knowledge" derived from other judicial proceedings were more likely than others to produce agreement. In five of the 21 prior knowledge scenarios there was nearly universal agreement or a dominant view, and in a further six scenarios a majority of the respondents favoured a single answer. On the other hand, there were still five scenarios in which only 40-49 percent of the respondents agreed on a single answer, and a further five scenarios where less than 40 percent of the respondents agreed on the most popular answer. 
Insert Chart 4

Another way of measuring the level of disagreement on scenarios is to set aside the "uncertain" responses and combine the responses of those who would definitely recuse themselves and those who would recuse themselves if a party raised an objection. The "uncertain" responses never made up more than 20 percent of the total responses for any question, and combining the responses that definitely favoured recusal with those that expressed qualified support for recusal always produced a predominant view and a minority view, which in any particular scenario either favours recusal (at least if a party raises an objection) or opposes recusal. What is interesting for these purposes is to compare the size of the minority view in different scenarios.

In nine of the 32 scenarios, less than 10 percent of the respondents supported the minority position. Accordingly, in just under one-third of the scenarios the respondents as a whole took a reasonably decisive position that recusal was or was not appropriate, though there may have been a stronger or weaker view that it would be better to wait and see if a party would object before making that decision. In another 13 scenarios, the minority position garnered more than 10 percent support but less than 30 percent support. In these scenarios there is clearly a predominant position with respect to the appropriateness of recusal, at least if a party objects, but the contrary view is far from insignificant. In the remaining ten scenarios, however, the minority position received the support of more than 30 percent of the respondents, and in three of those cases the minority position received more than 40 percent support. Accordingly, in nearly one-third of our scenarios a large minority of the judges disagreed with the basic attitude taken by a majority of their colleagues towards the question of whether it would be appropriate for the judge to recuse himself or herself if it were necessary to make a decision on this point.

Using this approach to measuring variation, the professional relationship scenarios still show considerable disagreement, with two of the five scenarios having a minority of more than 30 percent. There was more agreement on the "social relationship" scenarios, with a 
minority view of under 10 percent in four of the six scenarios, although disagreement on one scenario did reach the 30 percent level. Using this measure of variability, the results of the prior judicial knowledge scenarios were extremely mixed. In five of the 21 scenarios the minority view was supported by under 10 percent of the responses but, at the other end of the scale, in seven of the 21 scenarios the minority view was supported by more than 30 percent of the respondents, and in three of those seven the minority view garnered more than 40 percent support.

It should be recognized that there is an important distinction between a judge's attitude to the ultimate question of whether they would recuse if the issue were raised by a party in a particular situation, and the likelihood that the judge will actually recuse himself or herself in that situation. Combining the "definitely recuse" and the "recuse if a party objects" responses obscures this distinction. Even though we believe that determining a judge's attitude to whether recusal is warranted if an objection is raised is important in its own right, we must emphasize that judges who indicate that they would recuse themselves if a party objects may not always anticipate that an objection is likely to be forthcoming.

There are two reasons why a judge who would be willing to recuse himself or herself if a party objected might not, in fact, end up doing so in that situation. One possibility is that the parties may not object because they are unaware of the facts that might form the basis for a recusal application. We tested this possibility using a scenario that involves a situation in which a law partner of counsel, who is appearing before the judge in a child protection matter, has acted for the judge in an unrelated piece of litigation. ${ }^{17}$ This is a situation in which counsel for the party likely to raise an objection might well be unaware of the judge's client relationship with opposing counsel's law firm. Of the respondents who would recuse themselves on application from a party, 90 percent indicated that they would consult the parties but 10 percent would not. In the 10 percent of cases where the judge did not disclose the relationship to the parties, there is a substantial likelihood that no objection would be forthcoming.

Even in the 90 percent of the cases where the judge would consult the parties, it is not obvious that the parties will always raise an objection. Moreover, some judges may well take the likelihood that parties will object into account in selecting the answer that they would recuse, but only if a party objects. To test this possibility we considered how many of the judges who responded that they would recuse themselves if a party objects in the above child protection scenario also answered a separate question by indicating that they almost always recuse themselves on their own motion. ${ }^{18}$ It turned out that 58 percent of respondents who said that they would recuse themselves if a party objected in the above scenario also indicated that they would recuse themselves of their own motion more than 90 percent of the time. This suggests that even though these judges would recuse themselves if asked to do so in the above scenario, they do not necessarily assume that an objection will be forthcoming and indeed may well expect that an objection will not be forthcoming. counsel for the mother is a partner in a five person law firm. Within the past year, one of the lawyer's partners acted for you successfully in a claim against a builder for negligent construction of a renovation to your house. What courses of action would you take?"

18 Question B2 was worded as follows: "In what percentage of [cases in which you recuse yourself] do you recuse yourself of your own motion rather than because a party objects?” 
Some might find the level of disagreement we have identified among judges on a matter as central to the judicial role as the application of the rules governing impartiality unsettling, and we therefore believe that it is vital to provide some context for this aspect of our findings. First of all, it must be remembered that we were not giving judges a test to determine if they were able to identify the "correct" answer to a number of marginal scenarios; we were conducting an experiment to determine if the initial reactions of Canadian judges to different scenarios revealed a shared understanding of how the reasonable apprehension of bias test ought to be applied in a number of marginal cases. Not all cases where bias issues might arise are marginal. We did not ask about situations where a judge's spouse or child has a material interest in the outcome of a dispute because the answer to those cases is obvious. Our scenarios were identified on the basis of the comments we received from the judges that assisted us in developing the survey, who indicated to us that these types of cases seemed to cause difficulty in their jurisdictions. What the responses revealed was that in many instances these difficulties seem to be experienced by provincial and territorial judges across the country, and that some scenarios appear to cause more difficulty than others.

In addition, it is worth emphasizing that if judges have concerns about whether they should recuse themselves in a particular case, it is open to them to do research on the relevant case law, to consult their colleagues, and to seek submissions from counsel for the parties. Our survey results indicate that some judges (albeit a minority) do consult their colleagues regularly before deciding whether to recuse themselves, and in a number of the scenarios the most common response was to recuse oneself if a party objected, implying that the parties would have some opportunity to make submissions. In short, simply because our survey indicated a significant measure of variability in judicial responses to the potential recusal scenarios we posed to them, it does not follow that there is a corresponding degree of variability in the actual practice of Canadian provincial and territorial judges in recusing themselves in the full range of situations that confront them on a daily basis.

On the other hand, we do not wish to understate the practical significance of our findings for judges who are considering whether to recuse themselves in marginal cases. We did not design abstract scenarios that were intended to help us explore the deep structure of judicial thinking about the idea of impartiality in Canadian law. Rather, we chose scenarios that were intended to reflect the sorts of practical problems that Canadian provincial and territorial judges have to address on a reasonably regular basis. Moreover, it is not fanciful to think that in many instances Canadian judges make the determination of whether it is appropriate to sit in these types of situations based on their initial reactions to the types of material facts that we posed in the scenarios. As the Supreme Court of Canada rightly points out in Wewaykum, the addition of more information provides context that will sometimes shift our appreciation of the significance of the material facts, ${ }^{19}$ but in our view this does not prevent judges from offering an intelligent opinion on whether the reasonable apprehension of bias test is met based solely on the bare facts presented in our scenarios. ${ }^{20}$

Supra note 3 at para. 77 .

See e.g. Locabail (U.K.) Ltd. v. Bayfield Properties Ltd., [1999] EWCA Civ 3004, [2000] 1 Q.B. 451 at para. 25 [Locabail], where the Court provided a list of circumstances that were and were not likely to give rise to concerns with respect to perceived lack of impartiality. While the Court acknowledged that "[e]verything will depend on the facts," this did not prevent the Court from providing meaningful guidance with respect to fact situations that were, if anything, less elaborate than the scenarios we 


\section{How Did THE PARTiCipants RESPOND TO DIFFERENT RECUSAL SCENARIOS?}

The actual wording of the scenarios we asked our participants to address is found in the Appendix, below. ${ }^{21}$ Here we will simply refer to them by number and, for ease of reference, provide a brief description of the types of issues raised in each scenario. In reporting on the scenarios we have broken them down into the groupings identified in the questionnaire. In each instance we will provide a table setting out the data concerning the responses to the scenarios as a group and then comment on the responses to the specific questions.

\section{PROFESSIONAL RELATIONSHIP SCENARIOS}

Judges were all lawyers before they became judges, so it is normal that they will have professional relationships with other lawyers. The mere fact that a judge knew another lawyer professionally prior to their appointment to the bench will not, without more, give rise to a reasonable apprehension of bias if that lawyer appears before the judge as counsel. ${ }^{22}$ Nonetheless, it is clear that judges do not normally hear cases being argued by their former law partners, at least until after the passage of some reasonable "cooling-off” period. ${ }^{23}$ The jurisprudence offers judges a significant degree of latitude before their past or present relationships with lawyers who are conducting litigation will give rise to a reasonable apprehension of bias. ${ }^{24}$ On the other hand, relationships that do not form the basis for disqualification as a matter of law can be perceived to be uncomfortably close by some litigants, ${ }^{25}$ and this in turn can make recusal in a marginal case of this nature appear to be the most attractive course of action. ${ }^{26}$ We used five scenarios to consider the issue of recusal in situations in which the judge's professional relationship with the lawyer was something less than that of a partnership in a law firm, but more than a mere acquaintance as a fellow legal professional.

\section{constructed.}

21 The authors would be happy to forward a copy of the entire survey to any reader upon request.

22 See e.g. Locabail, supra note 20 at para. 25; Saxmere (No. 1), supra note 5; President of the Republic of South Africa v. South African Rugby Football Union, [1999] ZACC 9, [1999] 7 B. Const. L.R. 725 S.A. 147 (S. Afr. Const. Ct.) [S.A.R.F.U.]; Taylor, supra note 5.

23 See Canadian Judicial Council, Ethical Principles for Judges (Ottawa: Canadian Judicial Council, 1998) at 51-52, online: Canadian Judicial Council <http://www.cjc-ccm.gc.ca/cmslib/general/news pub_judicialconduct_Principles_1998_en.pdf $>$ [Ethical Principles]; Lorne Sossin, Philip Bryden \& Jay Brecher, Halsbury's Laws of Canada: Judges and Courts, 1st ed. (Markham, Ont.: LexisNexis, 2009) at HJC-32 and the cases cited therein. John Doe, 2007 BCSC 1231, [2007] B.C.J. No. 1809 (QL), aff'd 2008 BCCA 112, [2008] B.C.J. No. 576 (QL) [Makowsky].

25 See e.g. the decision of Goepel J. in Makowsky, ibid.

$26 \quad$ Ibid. at para. 17. 
TABLE 2 - Professional Relationship SCENARIOS

\begin{tabular}{|c|c|c|c|c|c|c|c|}
\hline Question & $\begin{array}{l}\text { Count / \% } \\
\text { of } \\
\text { Responses }\end{array}$ & $\begin{array}{l}\text { Definitely } \\
\text { Recuse } \\
\text { Yourself }\end{array}$ & Uncertain & $\begin{array}{l}\text { Recuse if } \\
\text { a Party } \\
\text { Objects }\end{array}$ & $\begin{array}{l}\text { Definitely } \\
\text { NOT } \\
\text { Recuse } \\
\text { Yourself }\end{array}$ & $\begin{array}{l}\text { Multiple } \\
\text { Answers }\end{array}$ & Total \\
\hline D1 & Count & 61 & 25 & 30 & 16 & 2 & 134 \\
\hline D2 & Count & 68 & 18 & 22 & 25 & 2 & 135 \\
\hline D3 & Count & 38 & 23 & 53 & 15 & 2 & 131 \\
\hline D4 & Count & 17 & 13 & 54 & 46 & 0 & 130 \\
\hline D5 & Count & 21 & 10 & 54 & 51 & 0 & 136 \\
\hline \multicolumn{8}{|c|}{ Percentages } \\
\hline D1 & $\%$ & 46 & 19 & 22 & 12 & 2 & $101^{*}$ \\
\hline $\mathrm{D} 2$ & $\%$ & 50 & 13 & 16 & 19 & 2 & 100 \\
\hline D3 & $\%$ & 29 & 18 & 41 & 12 & 2 & $102^{*}$ \\
\hline D4 & $\%$ & 13 & 10 & 42 & 35 & 0 & 100 \\
\hline D5 & $\%$ & 15 & 7 & 40 & 38 & 0 & 100 \\
\hline
\end{tabular}

*Percentages add up to more than 100 as a result of rounding to nearest whole number.

The first two scenarios (D1 and D2) concern professional conflict prior to the judge's appointment to the bench involving a lawyer now appearing before the judge representing the accused in a sexual assault case. In both scenarios the conflict was sufficiently serious that complaints were made to the Law Society. In D1, the judge had been the subject of a complaint by the lawyer that was dismissed by the Law Society, and in D2 the judge made a complaint about the lawyer that resulted in a reprimand. In both of these cases roughly half of the respondents believed that recusal would be appropriate, and if one adds the group of judges who would recuse themselves if a party objects, the support for recusal goes up to two-thirds of the respondents. Nevertheless, more than 10 percent of the respondents in D1 and nearly 20 percent in D2 definitely would not recuse themselves. This result is interesting because the possibility that the past antagonism would be perceived to operate to the disadvantage of the accused in a serious criminal matter was not sufficient to dissuade this group of judges from the view that recusal would not be appropriate at the outset of a trial. The other interesting feature of these two scenarios is the relatively high level of "uncertain" responses - more than 10 percent for D2 and nearly 20 percent for D1. This may be because the level of conflict with lawyers hypothesized by the scenarios is relatively unusual and judges may not have any experience with this type of situation. As we will see when we examine scenarios D4 and D5, which deal with friendly professional relationships between one of the lawyers and the judge prior to his or her appointment to the bench — scenarios that would be much more common - the number of "uncertain" responses drops fairly significantly.

Scenario D3 addresses a situation in which a law partner of counsel (from a small law firm) who is appearing before the judge in a child protection matter has acted for the judge in an unrelated piece of litigation. There was strong support for the proposition that recusal might be appropriate in these circumstances (70 percent of respondents), but it was split between those who indicated that they would recuse themselves if a party objected (41 percent) and those who would definitely recuse themselves (29 percent). Interestingly, the 
English Court of Appeal decision in Taylor ${ }^{27}$ could lend some support to the view that recusal would not be warranted in this situation, a position taken by just over 10 percent of the respondents. The Court in Taylor held that a judge who had received free legal services with respect to his will from the firm of the solicitors acting for one of the parties was not disqualified from hearing the case.

Scenarios D4 and D5 concern a reasonably close professional relationship between the judge and counsel prior to the judge's appointment to the bench. In each scenario the judge did not practice with the lawyer but was "well acquainted" with the lawyer both socially and through Canadian Bar Association and Law Society committee work. In addition, the judge and the lawyer often took part in the same charity golf events, and occasionally were part of the same foursome. The scenarios are identical except that in D4 the judge is hearing a small claims matter and in D5 the judge is trying a sexual assault case and the lawyer is appearing for the Crown. The results of the two scenarios are fairly similar. In D4, 42 percent of the respondents would recuse themselves if a party objects, whereas 40 percent gave this answer in D5. On the other hand, 13 percent responded that they would definitely recuse themselves in D4 whereas 15 percent gave this answer in D5, so in each scenario 55 percent of the respondents were willing to recuse themselves under some circumstances. A large minority definitely would not recuse themselves - 35 percent in D4 and 38 percent in D5. It is interesting to note that in the criminal law scenario, D5, there was a slight increase in both the number of judges who would definitely recuse themselves and the number who would definitely not recuse themselves. As we will see below, this result is somewhat at odds with the result in scenarios E1 and E2, in which the respondents were much more definite about recusing themselves from a criminal trial in which they had a social relationship with the accused than from a small claims trial in which they had the same type of social relationship with the defendant. The data does not suggest an obvious explanation for this divergence in results, and one can but speculate on the factors that might cause the difference. We will do so in Part D.3, below.

\section{SOCIAL RELATIONSHIP SCENARIOS}

It is well understood that judges may not adjudicate cases in which their family members or their close personal friends have a material interest. ${ }^{28}$ What is more difficult to decide is how close a social relationship has to be before recusal is appropriate. The jurisprudence reflects a number of factors that are relevant in determining whether a personal relationship is sufficiently close so as to cause a reasonable apprehension of bias. These factors include such things as the role that the person whom the judge has a relationship with is playing in the litigation, ${ }^{29}$ whether the relationship is direct or indirect, ${ }^{30}$ and whether the judge

$27 \quad$ Supra note 5.

See Ethical Principles, supra note 23 at 44-46; Sossin, Bryden \& Brecher, supra note 23 at HJC-31 and the cases cited therein.

29 For example, in Agar v. Morgan, 2003 BCSC 628, [2003] B.C.J. No. 939 (QL), there was no reasonable apprehension of bias where the trial judge was a neighbour of an expert witness whose credibility was not at issue in the trial.

30 In Man O’War Station Ltd. v. Auckland City Council (No. 1), [2002] UKPC 28, [2002] 3 N.Z.L.R. 577, for instance, the Privy Council held that a New Zealand Court of Appeal judge was not disqualified from hearing an appeal in a case where the principal witness at trial was the son of the judge's former law partner and professional mentor. See also Banyay v. Insurance Corp. of British Columbia (1996), 17 B.C.L.R. (3d) 216 (C.A.); Huchette c. Québec (1992), 12 C.R. (4th) 393 (Que. C.A.). 
considered the relationship to be sufficiently close that the judge would have difficulty resolving an issue in a manner that reflected adversely on that individual. ${ }^{31}$ We constructed six scenarios that were designed to explore this issue in different settings.

\section{TABLE 3 - SOCIAL RELATIONSHIP SCENARIOS}

\begin{tabular}{|c|c|c|c|c|c|c|c|}
\hline Question & $\begin{array}{l}\text { Count / \% } \\
\text { of } \\
\text { Responses }\end{array}$ & $\begin{array}{l}\text { Definitely } \\
\text { Recuse } \\
\text { Yourself }\end{array}$ & Uncertain & $\begin{array}{l}\text { Recuse if } \\
\text { a Party } \\
\text { Objects }\end{array}$ & $\begin{array}{l}\text { Definitely } \\
\text { NOT } \\
\text { Recuse } \\
\text { Yourself }\end{array}$ & $\begin{array}{l}\text { Multiple } \\
\text { Answers }\end{array}$ & Total \\
\hline E1 & Count & 51 & 10 & 61 & 9 & 0 & 131 \\
\hline E2 & Count & 81 & 9 & 39 & 7 & 0 & 136 \\
\hline E3 & Count & 39 & 17 & 58 & 20 & 1 & 135 \\
\hline E4 & Count & 28 & 9 & 49 & 47 & 0 & 133 \\
\hline E5 & Count & 114 & 5 & 12 & 0 & 0 & 131 \\
\hline E6 & Count & 78 & 6 & 35 & 7 & 1 & 127 \\
\hline \multicolumn{8}{|c|}{ Percentages } \\
\hline E1 & $\%$ & 39 & 8 & 47 & 7 & 0 & $101^{*}$ \\
\hline E2 & $\%$ & 60 & 7 & 29 & 5 & 0 & $101^{*}$ \\
\hline E3 & $\%$ & 29 & 13 & 43 & 15 & 1 & $101^{*}$ \\
\hline E4 & $\%$ & 20 & 7 & 37 & 36 & 0 & 100 \\
\hline E5 & $\%$ & 87 & 4 & 9 & 0 & 0 & 100 \\
\hline E6 & $\%$ & 60 & 5 & 30 & 5 & 1 & $101 *$ \\
\hline
\end{tabular}

*Percentages add up to more than 100 as a result of rounding to the nearest whole number.

Scenarios E1, E2, and E3 all deal with situations in which a person who has a casual social relationship with the judge is involved in the litigation. The nature of the relationship is described in the same terms in each scenario, ${ }^{32}$ but the type of legal proceeding and the acquaintance's role changes. In E1, the acquaintance is the defendant in a small claims case; in E2, the person is the accused in a prosecution for impaired driving; and in E3, the judge's acquaintance is the homeowner in a prosecution for breaking and entering, and the individual is not expected to appear as a witness.

In all three scenarios the dominant view was that recusal may be appropriate, and the main area of disagreement was whether the judge should definitely recuse himself or herself, or recuse only if a party objected. The support for definite recusal was strongest in the case of acquaintanceship with a criminal accused, E2, with 60 percent favouring definite recusal in comparison to 29 percent favouring recusal if a party objected. In E1 and E3, the support was strongest for recusal if a party objected (in E1, 47 percent were in favour of this option compared to 39 percent in favour of definite recusal, and in E3, 43 percent favoured recusal if a party objects compared to 29 percent who opted for definite recusal). Respondents who took the view that they definitely would not recuse themselves were in a distinct minority in 
all three scenarios (7 percent in E1, 5 percent in E2, and 15 percent in E3). Both the "uncertain" response (13 percent) and the "definitely not recuse” response (15 percent) went up in E3 in comparison to E1 and E2, indicating that a judge's social relationship with a victim of crime is considered a less clear-cut case for recusal than the judge's social relationship with a defendant in a civil case or an accused person in a criminal trial.

The distinct difference between the responses to E1 and E2 might lead one to believe that judges draw a sharp distinction between criminal and civil cases with respect to recusal, even though notionally the same test is being applied in both settings. On the other hand, the results of E3 suggest that the relationship between civil and criminal cases is not quite as simple as it might appear. In E3, the judge's social relationship with the victim of a crime might be thought to operate to the prejudice of the accused, whereas the judge's social relationship with the accused in E2 might be perceived to benefit the accused, or at least be a neutral factor. The responses to E3 were closer to the responses to the civil case, E1, than they were to the criminal law scenario, E2, where the judge's relationship was with the accused. Along with the similarity of treatment of scenarios D4 and D5, this result suggests that what makes the response to E2 distinctive is not that it involved a criminal as distinct from a civil case, but that it involved a relationship between the judge and an accused person that might be perceived to interfere with the impartial administration of justice.

Scenario E4 involves a small claims trial for failure to pay a bill in which the plaintiff is the owner of a grocery store at which the judge frequently shops. On the face of it, E4 seems similar to E1 except with respect to the particulars of the social relationship and the fact that in E1 the acquaintance is the defendant and in E4 the acquaintance is the plaintiff. Nevertheless, the responses to the two scenarios are quite different. Recall that in E1, 47 percent of the respondents indicated that they would recuse themselves if a party objected and 39 percent indicated that they definitely would recuse themselves. Only 7 percent of the respondents to E1 reported that they definitely would not recuse themselves. In E4, the largest response, at 37 percent, was once again that the judges would recuse themselves if a party objected. This time, however, 36 percent stated that they definitely would not recuse themselves, and only 20 percent indicated that they definitely would recuse themselves. It is difficult to say precisely what contributed to this decisive change in attitudes. It is not obvious that it should make a difference if the judge's relationship is with a plaintiff or a defendant in a civil case. The most likely explanation would seem to be that a substantial number of respondents perceived the judge's relationship with the owner of the grocery store to be less significant than the judge's relationship with a social acquaintance that the judge knew on a first name basis, whereas other respondents treated the relationships as essentially the same for the purposes of the application of the reasonable apprehension of bias test.

In scenarios E5 and E6, the judge's social relationship was with a key witness in a small claims trial. The difference between the two scenarios is that in E5 the witness is a close personal friend of the judge $\mathrm{e}^{33}$ and in E6 the witness is a close friend of one of the judge's children. ${ }^{34}$ Scenario E5 attracted the greatest degree of consensus among the respondents,

33 The relationship was described as follows: "You have known each other since you went to university together and you go out to dinner together several times a year."

34 The relationship was described as follows: "This individual has been to your home on numerous occasions, but the individual's friendship is with your child rather than with you personally.” 
with nearly 90 percent agreeing that they would definitely recuse themselves and another 9 percent indicating that they would recuse themselves if a party objected. There were no responses indicating that the judge definitely would not recuse himself or herself. There was slightly more disagreement about E6, but the dominant view was clearly that recusal would be appropriate. Definite recusal was favoured by 60 percent of the respondents and recusal if a party objects was favoured by another 30 percent. Nevertheless, it is interesting to note that 5 percent of the respondents definitely would not recuse themselves in these circumstances, and another 5 percent were uncertain.

\section{PRIOR JUdicial KNOWLEDGE SCENARIOS}

There is strong support in the case law for the proposition that a judge should not sit in appeal on one of his or her own decisions. ${ }^{35}$ It is also evident that, at least under normal circumstances, if a judge had involvement with a case as counsel or in some other capacity prior to his or her appointment to the bench, the judge must not hear that matter. ${ }^{36}$ It is also clear that, to at least some extent, different considerations apply when knowledge of the litigants or the relevant background facts of the case is derived through the judge's work as a judge. For example, the mere fact that a litigant has appeared before the judge before is not automatically a basis for disqualification. ${ }^{37}$ The issue that we explore in the following scenarios is the boundaries beyond which knowledge derived in a judicial capacity can give rise to a reasonable apprehension of bias.

\section{a. Bail Hearings}

The four bail hearing scenarios described below all involve situations in which the judge conducted the bail hearing and is now scheduled to conduct the trial. What varies is the information provided in the scenarios about the outcome of the bail hearing and the type of information given to the judge about the accused in the course of the bail hearing. In F1, interim release was granted. In F2, the accused was remanded into custody because he had no fixed address. In F3, the judge made an adverse credibility finding about the accused and ordered the accused remanded into custody. In F4, the judge received information about the accused's antecedents and criminal record and about the offence in the course of the bail hearing, but the scenario provides no information about what the material presented to the judge said about the accused or the outcome of the bail hearing.

See R. v. Alberta (Securities Commission) (1962), 36 D.L.R. (2d) 199 (Alta. S.C. (T.D.)); Glassman v. College of Physicians \& Surgeons (Ontario), [1966] 2 O.R. 81 (C.A.).

See Committee for Justice, supra note 1; Wewaykum, supra note 3; R. v. Catcheway, 2000 SCC 33, [2000] 1 S.C.R. 838.

In Locabail, supra note 20 at para. 25, the English Court of Appeal observed that " $[\mathrm{t}]$ he mere fact that a judge, earlier in the same case or in a previous case, had commented adversely on a party or witness, or found the evidence of a party or a witness to be unreliable, would not without more found a sustainable objection.” See also R. v. Werner, 2005 NWTCA 5, 205 C.C.C. (3d) 556; R. v. Tremblay, 2004 ABCA 102, [2004] A.J. No. 323 (QL); R. v. Perciballi (2001), 54 O.R. (3d) 346 (C.A.); Re Charkaoui, 2004 FC 624, 255 F.T.R. 199. 
TABle 4 - Bail Hearing Scenarios

\begin{tabular}{|c|c|c|c|c|c|c|c|}
\hline Question & $\begin{array}{l}\text { Count / \% } \\
\text { of } \\
\text { Responses }\end{array}$ & $\begin{array}{l}\text { Definitely } \\
\text { Recuse } \\
\text { Yourself }\end{array}$ & Uncertain & $\begin{array}{l}\text { Recuse if } \\
\text { a Party } \\
\text { Objects }\end{array}$ & $\begin{array}{l}\text { Definitely } \\
\text { NOT } \\
\text { Recuse } \\
\text { Yourself }\end{array}$ & $\begin{array}{l}\text { Multiple } \\
\text { Answers }\end{array}$ & Total \\
\hline F1 & Count & 14 & 11 & 60 & 45 & 0 & 131 \\
\hline F2 & Count & 13 & 10 & 35 & 72 & 0 & 130 \\
\hline F3 & Count & 93 & 7 & 28 & 3 & 1 & 132 \\
\hline F4 & Count & 43 & 12 & 49 & 25 & 0 & 129 \\
\hline \multicolumn{8}{|c|}{ Percentages } \\
\hline F1 & $\%$ & 10 & 8 & 44 & 33 & 0 & 100 \\
\hline F2 & $\%$ & 10 & 8 & 27 & 55 & 0 & 100 \\
\hline F3 & $\%$ & 71 & 5 & 21 & 2 & 1 & 100 \\
\hline F4 & $\%$ & 33 & 9 & 38 & 19 & 0 & 99* \\
\hline
\end{tabular}

*Percentages add up to more or less than 100 as a result of rounding to the nearest whole number.

The respondents to F1 assumed that the bail hearing was contested, but that bail was nevertheless granted. The opinions of our respondents was mixed in this situation, with 44 percent indicating that they would recuse themselves if a party objected, 33 percent indicating that they definitely would not recuse themselves, and 10 percent stating that they definitely would recuse themselves. In F2 (no fixed address), the majority view was that the judge should not recuse himself or herself. On the other hand, 27 percent of the respondents would recuse themselves if a party objected and a further 10 percent would definitely recuse themselves. By contrast, the almost universal view in F3 (adverse credibility finding) was that recusal may be appropriate, and the main issue was whether the judge should definitely recuse himself or herself (71 percent), or recuse only if a party objected (21 percent). The largest response to F4 was to recuse if a party objects (38 percent), but one-third of the judges (33 percent) thought that possession of information about the accused's record and the offence was a sufficient basis for recusal regardless of what the information said. It is worth noting, however, that nearly 20 percent of the respondents definitely would not recuse themselves in this situation.

Taken overall, these results support the view that a negative credibility finding that is sufficiently significant to support a remand of the accused into custody creates sufficient problems that the judge should not hear the trial of the offence, though there is some support for the view that the judge should be able to conduct the trial if a party (presumably the accused) does not object. On the other hand, the majority view is that the mere fact that a judge remanded the accused into custody for reasons unconnected to the accused's character or the circumstances of the offence is not a sufficient basis for preventing the judge from hearing the trial of the offence. This was by no means a universal view, however, and there was considerable support for the view that the judge should not hear the case if the accused objects, and some support for recusal even if there is no objection. Indeed, 10 percent of the respondents would definitely recuse themselves at trial even if they had granted bail, suggesting that this group of judges believes that recusal is warranted simply because, in the context of a contested bail hearing, the judge will have begun forming an opinion of the accused even if that opinion is not sufficiently unfavourable to warrant the denial of bail. 
The possession of information about both the accused and the offence (F4) was the most confusing fact situation for respondents. Nearly 40 percent thought that recusal was appropriate if a party (again, presumably the accused) objects and one-third thought that there was a sufficient basis for recusal regardless of whether there was an objection. On the other hand, nearly 20 percent definitely would not recuse themselves in this situation, leading one to speculate that in the minds of these judges the issue may be whether the judge has information that is damaging to the accused and not simply whether the judge has some knowledge about the accused and the offence that may end up being relevant to the trial. It is also possible, of course, that some of these judges would not have favoured recusal even if the information was damaging.

\section{b. Subsequent/Multiple Trials}

The next nine scenarios deal with the difficulties that can arise when a judge has presided over a trial involving a particular individual, and that individual now appears before the judge as a party in another trial. What differentiates these scenarios from bail hearings is that, on the one hand, the judge will typically learn a good deal more about the individual in the context of a trial than in the setting of a bail hearing, but on the other hand the connection between the initial proceeding and the subsequent trial will sometimes be more tenuous than is the case with bail hearings. Four of the nine scenarios (F6, F7, F8, and F9) involve different types of situations in which a judge has tried and convicted an individual previously and is now scheduled to try that individual for another alleged offence that is unrelated to the previous offence. Scenarios F10 and F11 deal with situations in which a judge is scheduled to hear trials involving two different accused persons concerning separate but related incidents that allegedly took place on the same day. In F10, participants were asked whether they would recuse themselves from the second trial regardless of what evidence was adduced at the first trial. Scenario F11 changes the situation by indicating that the judge heard evidence concerning the second alleged incident in the course of a sentencing hearing after convicting the first accused. Scenarios F12 and F13 explore recusal in the context of related civil and criminal trials. Scenario F12 concerns a spousal assault case involving the same parties who have appeared before the judge in the context of an application for spousal support. Scenario F13 deals with a child protection case in which the judge had remanded the father into custody on a charge relating to his child. Finally, F14 deals with a situation in which the judge has sentenced the accused on a number of previous occasions in the recent past for property-related offenses and is now scheduled to try the accused on a charge of receiving stolen property. 
TABLE 5 - SubSEQUENT / Multiple Trials

\begin{tabular}{|c|c|c|c|c|c|c|c|}
\hline Question & $\begin{array}{l}\text { Count / \% of } \\
\text { Responses }\end{array}$ & $\begin{array}{l}\text { Definitely } \\
\text { Recuse } \\
\text { Yourself }\end{array}$ & Uncertain & $\begin{array}{l}\text { Recuse } \\
\text { if a } \\
\text { Party } \\
\text { Objects }\end{array}$ & $\begin{array}{l}\text { Definitely } \\
\text { NOT } \\
\text { Recuse } \\
\text { Yourself }\end{array}$ & $\begin{array}{l}\text { Multiple } \\
\text { Answers }\end{array}$ & Total \\
\hline F6 & Count & 8 & 9 & 48 & 67 & 0 & 132 \\
\hline F7 & Count & 5 & 9 & 49 & 68 & 1 & 132 \\
\hline F8 & Count & 13 & 10 & 54 & 55 & 1 & 133 \\
\hline F9 & Count & 45 & 18 & 46 & 22 & 1 & 132 \\
\hline F10 & Count & 55 & 24 & 35 & 16 & 1 & 131 \\
\hline F11 & Count & 54 & 18 & 43 & 17 & 1 & 133 \\
\hline F12 & Count & 13 & 15 & 48 & 48 & 0 & 124 \\
\hline F13 & Count & 37 & 23 & 42 & 21 & 1 & 124 \\
\hline F14 & Count & 22 & 8 & 54 & 47 & 0 & 131 \\
\hline \multicolumn{8}{|c|}{ Percentages } \\
\hline F6 & $\%$ & 6 & 7 & 36 & 51 & 0 & 100 \\
\hline F7 & $\%$ & 4 & 7 & 37 & 52 & 1 & $101^{*}$ \\
\hline F8 & $\%$ & 10 & 8 & 41 & 41 & 1 & $101^{*}$ \\
\hline F9 & $\%$ & 34 & 14 & 35 & 17 & 1 & $101 *$ \\
\hline F10 & $\%$ & 42 & 18 & 27 & 12 & 1 & 100 \\
\hline F11 & $\%$ & 41 & 14 & 32 & 13 & 1 & $101^{*}$ \\
\hline F12 & $\%$ & 11 & 12 & 39 & 39 & 0 & $101^{*}$ \\
\hline F13 & $\%$ & 30 & 19 & 34 & 17 & 1 & $101 *$ \\
\hline F14 & $\%$ & 17 & 6 & 41 & 36 & 0 & 100 \\
\hline
\end{tabular}

*Percentages add up to more than 100 as a result of rounding to the nearest whole number.

Scenario F6 presents, in its simplest form, the question of whether it is appropriate for a judge to try an accused after the judge has tried and sentenced that individual to six months imprisonment on an unrelated charge. The majority view of the respondents was that they would not recuse themselves in this situation, and this view seems to be consistent with the case law, which suggests that the mere fact that an individual has appeared before a judge in the past is not a sufficient basis to require that the judge not hear a case involving that individual. ${ }^{38}$ Nevertheless, there appears to have been sufficient discomfort (perhaps also arising from the possibility that information from the first trial would improperly influence the second trial) that 36 percent of the respondents indicated that they would recuse themselves if a party objected, and a further 6 percent of the respondents would definitely recuse themselves.

Scenarios F7 and F8 were designed to introduce additional information about whether the accused, who has been previously convicted and sentenced, would appear as a witness. In 
F7, the accused was not expected to testify, and in F8 the accused was expected to testify. ${ }^{39}$ As one might expect, the responses to F7 essentially mirrored those for F6, since the additional information that the accused was not expected to testify was probably consistent with the expectation respondents had when they considered F6. The additional information that the accused was expected to testify in F8 did influence some judges, but by no means the majority. Whereas the majority of judges would not have recused themselves in F6 and F7, the proportion who gave the same answer to F8 was reduced to 41 percent. Those who would recuse themselves if a party objected increased to 41 percent from 36 percent in F6 and 37 percent in F7, and those who would definitely recuse themselves increased to 10 percent.

Scenario F9 was in many ways the most interesting of the four scenarios because the individual who had been previously convicted and was the subject of a negative credibility finding by the judge is to be the principal witness for the defence in the trial of another person. Here, the dominant view was that the respondents would either recuse themselves (34 percent) or recuse themselves if a party objects (35 percent). Nevertheless, 17 percent of the respondents definitely would not recuse themselves in this situation. It is interesting to compare this result to F3, in which judges were asked to assume that they had made a negative credibility finding against the accused at a bail hearing. It will be recalled that in that situation only 2 percent of the respondents definitely would not recuse themselves and 71 percent definitely would recuse themselves. For some judges, therefore, a negative credibility finding involving the accused in a previous proceeding gives rise to more concerns than a previous negative credibility finding involving a key defence witness.

The predominant view expressed in $\mathrm{F} 10^{40}$ was that it was not appropriate for a judge to hear both trials where two individuals have been charged in relation to separate but related incidents. Forty-two percent of the respondents indicated that they would definitely recuse themselves in this situation, and another 27 percent would recuse themselves if a party objected. The addition of information in F11, that evidence that would clearly be relevant to the second trial was adduced in the sentencing hearing of the first accused, did not significantly change the responses. Thus, 41 percent of respondents said that they would definitely recuse themselves in F11, and a further 32 percent indicated that they would recuse themselves if a party objected. Once again, it is worth noting that 12 percent of the respondents in F10 and 13 percent of the respondents in F11 stated that they definitely would not recuse themselves in this situation.

Scenarios F12 and F13 provide another opportunity to explore the question of whether judges are automatically more likely to recuse themselves in a criminal case than in a civil case that raises a similar basis for deciding not to sit. Once again, the results of these scenarios suggest that the answer to this question is not self-evident. In F12, the participants were asked to consider whether they would recuse themselves in a criminal trial for spousal assault after they had made a support order for the spouse in a civil proceeding. The

39 Although not relevant for the present analysis, F7 and F8 both stated that "[a] recusal would likely involve some delay."

Scenario F10 was worded as follows: "There are two separate informations, one against A for assault on B, the other against B for uttering a threat against A. Both incidents allegedly occurred on the same day. You are schedule to conduct both trials. What courses of action would you take?” 
respondents were evenly split between those who definitely would not recuse themselves in this situation (39 percent) and those who would recuse themselves if a party objected (39 percent). Only 11 percent indicated that they would definitely recuse themselves. In F13, ${ }^{41}$ on the other hand, the percentage of respondents who would definitely recuse themselves increased to 30 percent, and the percentage who definitely would not recuse themselves dropped to 17 percent. The percentage of respondents who would recuse themselves if a party objected dropped slightly to 34 percent, and an uncharacteristically high 19 percent indicated that they were uncertain. The fact that F12 dealt with a criminal case and F13 did not clearly failed to induce more respondents to indicate that they would recuse themselves in F12. On the other hand, it may be that some respondents considered the stakes to be higher in the child protection scenario (F13) than in the spousal assault scenario (F12), and this would be consistent with the broader idea that judges are more willing to recuse themselves in situations where they believe that the case over which they are called upon to preside has particular significance to one or more of the parties.

The responses to $\mathrm{F} 14^{42}$ were interesting because they suggest that some judges are more concerned about the appearance of impartiality when they are dealing with an accused with whom they have had multiple contacts than they are when dealing with an accused whom they had tried and convicted only once. Just over 40 percent of the judges were prepared to recuse themselves in this situation if a party objected, compared to 36 percent who would have taken the same action in F6, which dealt with the trial of an accused whom the judge had convicted and sentenced only once. Similarly, 17 percent of the respondents would definitely recuse themselves in F14, compared to only 6 percent in F6. It is still the case, however, that a substantial proportion of the respondents definitely would not recuse themselves in either situation, although the percentage drops from 51 percent in F6 to 36 percent in F14.

\section{c. Subsequent Related Proceedings}

The final eight scenarios build to some extent on what we learned in the previous 13 . What differentiates them is some feature of either the proceeding in which previous judicial knowledge was acquired, or the subsequent proceeding in which the knowledge gained might be relevant, that takes it outside the bail hearing or trial setting. These scenarios include preliminary inquiries (F15 and F16), hearings concerning breaches of conditional orders (F17 and F18), dangerous offender and long-term offender proceedings (F19), the issuance of search warrants (F20), civil mediation proceedings (F21), and civil proceedings in which estoppel based on an earlier decision of the judge is being raised as a defence (F22). now trying the accused on a charge of receiving stolen property. 
TABle 6 - Subsequent Related Proceedings

\begin{tabular}{|l|l|l|l|l|l|l|l|}
\hline Question & $\begin{array}{l}\text { Count / \% } \\
\text { of } \\
\text { Responses }\end{array}$ & $\begin{array}{l}\text { Definitely } \\
\text { Recuse } \\
\text { Yourself }\end{array}$ & Uncertain & $\begin{array}{l}\text { Recuse } \\
\text { if a } \\
\text { Party } \\
\text { Objects }\end{array}$ & $\begin{array}{l}\text { Definitely } \\
\text { NOT } \\
\text { Recuse } \\
\text { Yourself }\end{array}$ & $\begin{array}{l}\text { Multiple } \\
\text { Answers }\end{array}$ & Total \\
\hline F15 & Count & 3 & 5 & 23 & $\mathbf{1 0 2}$ & 0 & 133 \\
\hline F16 & Count & 3 & 2 & 29 & $\mathbf{1 0 0}$ & 0 & 134 \\
\hline F17 & Count & 0 & 1 & 7 & $\mathbf{1 2 8}$ & 0 & 136 \\
\hline F18 & Count & 2 & 3 & 20 & $\mathbf{1 0 7}$ & 0 & 132 \\
\hline F19 & Count & $\mathbf{7 3}$ & 18 & 32 & 9 & 0 & 132 \\
\hline F20 & Count & $\mathbf{7 8}$ & 9 & 33 & 10 & 1 & 131 \\
\hline F21 & Count & $\mathbf{6 8}$ & 12 & 40 & 7 & 0 & 127 \\
\hline F22 & Count & $\mathbf{3 9}$ & 25 & 27 & 33 & 0 & 124 \\
\hline & & & $\mathbf{P e r c e n t a g e s}$ & & & \\
\hline F15 & $\%$ & 2 & 4 & 17 & $\mathbf{7 7}$ & 0 & 100 \\
\hline F16 & $\%$ & 2 & 2 & 22 & $\mathbf{7 5}$ & 0 & $101^{*}$ \\
\hline F17 & $\%$ & 0 & 1 & 5 & $\mathbf{9 4}$ & 0 & 100 \\
\hline F18 & $\%$ & 1 & 2 & 15 & $\mathbf{8 1}$ & 0 & $99 *$ \\
\hline F19 & $\%$ & $\mathbf{5 5}$ & 14 & 24 & 7 & 0 & 100 \\
\hline F20 & $\%$ & $\mathbf{6 0}$ & 7 & 25 & 8 & 1 & $101^{*}$ \\
\hline F21 & $\%$ & $\mathbf{5 4}$ & 9 & 31 & 6 & 0 & 100 \\
\hline F22 & $\%$ & $\mathbf{3 1}$ & 20 & 22 & 27 & 0 & 100 \\
\hline
\end{tabular}

*Percentages add up to more or less than 100 as a result of rounding to the nearest whole number.

The dominant view (77 percent) of the respondents to F15 was that they would not recuse themselves if called upon to hear a preliminary inquiry after having remanded the accused into custody. Seventeen percent would recuse themselves in this situation if a party objected, but only 2 percent would definitely recuse themselves if faced with this situation. Scenario F16 produced similar results. Seventy-five percent of respondents definitely would not recuse themselves if called upon to sentence an accused who re-elected and pleaded guilty after the judge had heard the preliminary inquiry. Once again, some respondents (22 percent) would recuse themselves if a party objected, but only 2 percent would definitely recuse themselves.

The results were even more decisive when the participants were asked if they would recuse themselves if called upon to adjudicate a breach hearing with respect to a conditional sentence they had issued (F17). Ninety-four percent of the respondents stated that they would not recuse themselves in this situation. Only 5 percent indicated that they would recuse themselves if a party objected, and no respondent would definitely recuse himself or herself. This was the most decisive result in the entire survey, and it appears to reflect a widespread practice for the judge who issued a conditional sentence to conduct any breach hearing in respect of that sentence. Under these circumstances, it is interesting to note that a small minority of judges would recuse themselves if a party objected. In some instances this may simply be a product of lack of familiarity with the usual practice in this type of case, but it may also reflect a philosophical reluctance on the part of some judges to hear cases in which 
a party is not comfortable with them as an adjudicator. We will return to this theme in Part D.5, below.

In F18, participants were told that they remanded the accused into custody for a breach hearing in what they assumed was a contested proceeding. They were then asked if they would recuse themselves from the breach hearing itself. Once again, the dominant view of the respondents (81 percent) was that they definitely would not recuse themselves in this situation. Fifteen percent of respondents would, however, recuse themselves if a party objected, and an additional 1 percent definitely would recuse themselves in this situation.

Scenario F19 asked participants whether they would recuse themselves from a long-term offender hearing with respect to an individual after a successful appeal from the judge's finding that the individual was a dangerous offender. Here there are two potential sources of prejudice. First, the judge may be unconsciously influenced by evidence adduced in the dangerous offender proceeding that is not adduced in the long-term offender hearing. The second concern is the perception that the judge might be influenced, consciously or unconsciously, by a belief that the appellate ruling was incorrect. Not surprisingly, the dominant view was that respondents would definitely recuse themselves (55 percent) or recuse themselves if a party objected (24 percent). It is worth noting once again, however, that a small minority of judges ( 7 percent) definitely would not recuse themselves in this situation. This may be the result of a desire of some judges to reinforce the idea that they have no stake in the outcome of appeals of their decisions, and that they are able to assess the evidence before them objectively notwithstanding views that they may have formed when dealing with the individual being sentenced.

Scenario F20 asked if participants would recuse themselves from hearing a trial if they had issued a search warrant, based in part on affidavit evidence that would be inadmissible at trial, where the search yielded evidence that would be introduced at the trial. The results of this scenario were very similar to F19, with 60 percent of respondents indicating that they would definitely recuse themselves, a further 25 percent indicating that they would recuse if a party objected, and 8 percent answering that they definitely would not recuse themselves.

In F21, we shifted our focus from criminal proceedings to court-annexed mediation of a civil proceeding. The participants were asked to assume that the mediation rules do not guarantee parties that if their case is not settled it will be heard by a different judge than the one who took part in the mediation. The participants were then asked to indicate if they would hear the trial of a case that they had mediated, but did not result in a settlement. The dominant answer was that the judges would not conduct a trial in this situation. More than half (54 percent) indicated that they would definitely recuse themselves, and another 31 percent would recuse themselves if a party objected. Six percent of the respondents indicated that they definitely would not recuse themselves in this situation. This may reflect a belief on the part of at least some of these judges that if the rules do not specify that the judge who mediated will not hear cases that do not result in settlement, it is inappropriate for a judge who mediated a case that did not settle to refuse to try the matter.

Finally, F22 asked if participants would try a small claims case in which the defendant was pleading an estoppel based on one of the judge's own decisions. This scenario seemed 
to give the respondents a great deal of difficulty. An unusually high percentage of the respondents (20 percent) said that they were uncertain what they would do in this situation. The remaining responses were almost evenly divided: 31 percent said that they would definitely recuse themselves, 22 percent stated that they would recuse themselves if a party objected, and 27 percent indicated that they definitely would not recuse themselves.

\section{ARE THERE EXPLANATIONS FOR DIFFERENT RESPONSES TO RECUSAL SCENARIOS?}

The first thing that is evident to us from the foregoing summary of the results of the 32 scenarios is that recusal is a complex phenomenon and that there is no simple explanation for the variation in the participants' responses to the scenarios that we posed to them. For example, as we will explain below, we believe that one important reason some judges are more willing to recuse themselves than others is that some judges are more reluctant than others to place themselves in a position in which at least one of the parties would rather have the case heard by another judge. But, by itself, this explanation does not account for why this sensitivity to the sensibilities of parties is manifested more strongly in some scenarios than in others. To put this observation a different way, if different judicial philosophies with respect to recusal were the overwhelming consideration in determining when judges will and will not recuse themselves, one would expect to see a reasonably consistent pattern of recusal and willingness to sit across the 32 scenarios we studied. We would not be surprised if judges disagreed with each other, but we would expect the extent of the disagreement to be fairly stable.

In fact, this is not the pattern of disagreement that we see at all. In roughly one-third of the scenarios there is a substantial level of agreement, at least on the question of whether recusal would be warranted if a party raised an objection, though in most of those scenarios there is also a distinct minority view. In another one-third of the scenarios, however, the minority view grows to between 10 and 30 percent, suggesting that many judges are willing to shift their views and are not wedded to either a majority or a dissident view. In the final one-third of the scenarios the level of disagreement is sufficiently strong that it is difficult to say that there is a clear majority position.

The varying levels of disagreement suggest that considerations come into play in certain situations that are either not evident or are insignificant in others. We identified five considerations that seemed to be likely candidates to have at least some influence on the different responses we received to the scenarios presented or otherwise explain the information received through the survey. The first is the different assessments that judges make of the practical implications for the efficient administration of justice on their willingness to recuse themselves in different types of situations. The second is the extent to which judges perceive that parties are raising recusal in order to gain a tactical advantage rather than as the result of a genuine concern about the presence of a reasonable apprehension of bias. The third is the extent to which judges are influenced by a sense that they should be more willing to recuse themselves where the outcome of the dispute is of greater significance to the parties than they should in situations where the stakes are lower. The fourth is the extent to which judges are or are not aware of the common practice of their 
colleagues. The fifth is the different degrees of sensitivity judges have to the perceptions of the parties. ${ }^{43}$ We will address each of these considerations in turn.

\section{PRACTICAL IMPLICATIONS FOR THE EFFICIENT ADMINISTRATION OF JUSTICE}

In her comment on the criteria identified by the English Court of Appeal in the Locabail ${ }^{44}$ decision regarding where applications for the disqualification of judges should and should not succeed, Kate Malleson argued that the guidelines were "an essentially pragmatic attempt to protect the efficient operation of the court system over a purist application of the Hewart principle of justice [referring to Lord Hewart's observation that justice should clearly be seen to be done]." 45 It seemed likely to us that judges' perceptions of the practical implications for the litigants and the efficiency of their courts would have some influence on the willingness of judges to recuse themselves. In particular, we hypothesized that judges who sit in smaller communities would be more reluctant to recuse themselves than their colleagues who sit in larger urban locations, because it would normally be easier to find a different judge to hear the case in a larger centre than a smaller one. What we discovered was that this hypothesis held true with respect to recusal based on professional relationships, but was less pronounced in scenarios involving personal relationships and was barely noticeable in scenarios involving knowledge acquired in other judicial proceedings.

Specifically, in the D scenarios (dealing with professional relationships) we found that there was little change in the percentage of judges sitting in smaller centres who were uncertain or would recuse on application only compared to judges sitting in communities with a population larger than 25,000. However, there was a significant difference between the number of judges who would definitely recuse or definitely not recuse. While 35 percent of judges in urban centres would definitely recuse in these scenarios, only 18 percent of their rural counterparts would recuse. Similarly, 21 percent of judges in urban centres would definitely not recuse themselves, while 32 percent of rural judges would opt not to recuse themselves. helped us better understand the role these factors might play in the responses given by the participants in our survey. 
Insert Chart 5

The differences in social relationship scenarios (E scenarios) were visible, but the degree of difference was weaker.

Insert Chart 6 
Again, there was little change in the degree of uncertainty or in the response to recusal applications, but some difference in the definite recusal and definitely not recusal responses. Rural judges were somewhat more reluctant to definitively recuse. Interestingly, rural judges who were reluctant to recuse themselves did not tend to gravitate toward the intermediate option of recusing themselves if a party objected. Thus, the decrease in the percentage of rural respondents compared to urban respondents who indicated that they would definitely recuse themselves is almost completely offset by an increase in the percentage of rural respondents who would definitely not recuse themselves.

For the scenarios involving prior judicial knowledge we found that the rural/urban divide all but disappeared.

Insert Chart 7

The idea that efficiency considerations would influence judges' decisions on whether to recuse themselves in marginal cases was reinforced by the comments that we received when we asked participants to identify circumstances that would change their answers to any of the professional relationship or social relationship scenarios. We received 33 comments in response to question D6 and 22 comments in response to question E7, which invited judges to identify circumstances that would change their answers to the questions in that section of the survey. Most of the responses to E7 mirrored the responses to D6. The most common answer (12 of the responses to D6 and 13 of the responses to E7) was that the availability of another judge to hear the case would make a difference, especially where the judge facing a potential recusal situation was hearing cases on circuit. The comments were usually brief, and it was difficult to discern if the principal concern was the impact on parties that would be the result of delay in finding another judge to hear the matter or the negative consequences of shifting the workload of adjudication onto other judges. On the whole, the impact on parties seemed to be the dominant concern, as is illustrated by the observation of one 
participant who commented that if both parties agreed that recusal would be appropriate, that would be determinative of the question of recusal from that judge's point of view.

\section{PARTIEs SEEKING Recusal FOR TACTICAL REASONS}

Scenario D2 ${ }^{46}$ was the only scenario in which we indicated that the judge was being asked to recuse himself or herself. In all of the others, the participants were simply presented with a fact pattern and a number of options, which included the possibility that a judge would recuse himself or herself if a party raised an objection. The answers to D2 were not dramatically different from the answers to the companion scenario, D1, in which the lawyer who had been in conflict with the judge prior to the judge's appointment to the bench did not make an application that the judge recuse himself or herself. Nevertheless, a number of judges (11 in response to questions regarding professional relationships and four in response to questions regarding social relationships) did comment that if they believed that a party was seeking the judge's recusal in order to gain a tactical advantage in the litigation, this would influence their thinking. Of course, parties do not announce in court that they are raising the issue of a reasonable apprehension of bias in order to delay an outcome that is expected to be unfavourable or to otherwise gain a tactical advantage. For this reason, we did not think it was productive to attempt to explore how often judges find themselves reluctant to recuse themselves because they suspect that a recusal application is tactically motivated. On the other hand, it is worth noting as a distinct consideration that was identified by a number of judges who participated in our survey.

\section{Heightened Sensitivity IN “High StAKES” CASES}

In the course of providing guidance on when objections based on a perception of lack of impartiality on the part of a judge should and should not be sustained, the English Court of Appeal observed in Locabail that "[e]verything will depend on the facts, which may include the nature of the issue to be decided." 47 The Court did not elaborate on what was intended by this passage, but it is at least conceivable that it would be appropriate for judges to take into account the practical significance of the dispute to the parties in deciding whether recusal is warranted in a particular situation. Once again, it may not be easy for a judge to weigh the relative significance of different types of disputes. One would normally anticipate that a criminal charge would be of greater significance than a civil dispute, but does this calculus hold true if the charge involves little likelihood of imprisonment and the civil matter could affect an individual's livelihood or ability to maintain their home? The comment of one participant suggests that not all criminal charges will be treated in the same manner when a judge is deciding whether to recuse in a marginal situation. This judge observed: "sexual cases in small towns are very sensitive and require a higher standard to ensure the appearance of justice is well served.”

Our analysis of scenarios that raise a similar factual basis for recusal in both civil and criminal matters provides some support for the proposition that judges are more likely to

$46 \quad$ Involving a lawyer who had been reprimanded by the Law Society as a result of a complaint made by the judge before his or her appointment to the bench.

Supra note 20 at para. 25. 
recuse themselves in a criminal case than in a civil case involving comparable grounds for recusal, but the evidence is ambiguous at best.

Scenarios E1 and E2 set out the social relationship that might form the basis for recusal in precisely the same terms, but judges were much more likely to indicate that they would definitely recuse themselves in the criminal case (E2) than in the civil case (E1). On the other hand, respondents were more likely to recuse themselves if a party objected in E1 than in E2, so the main effect of the difference between the civil and criminal scenarios was that in the criminal case judges were more likely to recuse themselves outright, whereas in the civil case they were more likely to wait to see if a party objected before deciding to recuse themselves.

Scenarios D4 and D5 also offer the same fact pattern in the context of a civil and a criminal proceeding, this time raising the judge's prior professional relationship with counsel as a possible basis for recusal. This time there was very little difference in the way the respondents treated the two scenarios.

Finally, F12 and F13 explore the extent to which knowledge gained as a result of previously adjudicating a related case would induce judges to recuse themselves from the trial of a spousal assault case (F12) on the one hand and a child protection hearing (F13) on the other. In this instance, the respondents were more likely to recuse themselves in the civil matter (F13) than in the criminal one (F12). As we noted earlier, this might be a situation in which the child protection matter was considered to have consequences for the parties that were as serious as the spousal assault case. ${ }^{48}$ There is support in the jurisprudence for the proposition that child protection hearings are a special kind of civil proceeding in that they engage interests protected by s. 7 of the Canadian Charter of Rights and Freedoms, ${ }^{49}$ which is not ordinarily true of other civil proceedings. ${ }^{50}$

Overall, the scenarios in which we compare willingness to recuse in civil and criminal matters suggest that a judge's perception of the seriousness of a case may influence their decision in some instances, but it is difficult to predict how much weight will be given to this factor in any particular instance.

\section{Problems With Rule Penetration}

One reason for variability may be that judges are simply unaware of what their colleagues are doing. As we indicated earlier, our study suggested that it is relatively common for judges

In Marshall v. Marshall, 2008 NLUFC 13, 277 Nfld. \& P.E.I.R. 11 at para. 15, the Newfoundland and Labrador Unified Family Court further notes the importance of considering the interests of non-parties, (that is, the child or children in family law proceedings) when determining a bias application: Finally, in the family law context, continuity with regard to judicial decision-makers has been recognized as being beneficial in custody and access proceedings where the best interests of children is the paramount consideration. Unlike other judicial proceedings where usually only the parties' interests are at stake, in child custody and access matters a third usually silent interest must be primarily considered. Judges who hear evidence form opinions and make judgments based upon the evidence presented at that time. Therefore, it has been held that subsequent applications for variation are often times best heard and decided by the judge who first made an order in the matter. (See, for example, J. (G.J.W.), Re (2002), 332 A.R. 194 (Alta. Prov. Ct.); Roy c. Cyr, [1996] N.B.J. No. 25 (N.B. C.A.)).

$49 \quad$ Part I of the Constitution Act, 1982, being Schedule B to the Canada Act 1982 (U.K.), 1982, c. 11.

50 Compare New Brunswick (Minister of Health and Community Services) v. G.(J.), [1999] 3 S.C.R. 46, with Blencoe v. British Columbia (Human Rights Commission), 2000 SCC 44, [2000] 2 S.C.R. 307. 
to recuse themselves of their own motion, in which case there will rarely be a written decision recording their reasons for doing so. Moreover, it is relatively uncommon for judges to consult a colleague before deciding whether to recuse themselves. All of this is suggestive of the possibility that in some instances judges do not follow practices that are common among their colleagues because they are not aware of what these practices are. Indeed, one of our motivations in conducting this study was to help identify areas in which Canadian provincial and territorial judges do and do not share a common understanding of whether recusal is appropriate.

One piece of evidence that supports the view that lack of awareness of common practice may be an issue is the result of our questions concerning whether in the participant's jurisdiction there were accepted "cooling-off” periods following which it was acceptable for judges to hear cases involving their former law firm or a former client. In both instances the question asked the judge to assume that they had no personal knowledge of the facts of the case, so the only issue is whether there is a common understanding about how much time has to pass before a judge can hear cases involving their former law firm or clients. As the following bar graphs illustrate, the most common answer to this question was "no," but in most jurisdictions a number of judges answered "yes."

Insert Chart 8

Based on survey responses, there are fewer bright line rules in place for cooling-off periods in relation to former clients; or, at the very least, judges are less aware of bright line rules in this area. As the following bar graph illustrates, however, in most places there is a mix of views on whether there is an accepted cooling-off period before a judge can hear a case involving a former client. 
Insert Chart 9

We considered the possibility that judges at different stages of their careers on the bench might have different understandings with respect to the presence of an accepted cooling-off period. The cooling-off period is relevant to recusal situations that a judge is facing at the early stages of his or her career, so it would not be surprising if judges who are in the first five years of their careers have a different understanding of the accepted practice in this area than their more senior colleagues. We examined two jurisdictions from which we had a reasonably large number of responses (Nova Scotia and Ontario) to see if there was any correlation between years of experience as a judge and views concerning whether there was an accepted cooling-off period with respect to the judge's former law firm and clients. What we found is that there was no evident correlation between experience on the bench and views with respect to whether there is an accepted cooling-off period in the jurisdiction. The only apparent exception to this rule was that the Nova Scotia and Ontario respondents who were in their first five years on the bench all agreed that there was no accepted cooling-off period with respect to former clients in their jurisdiction. On the other hand, very few respondents in any experience category believed that there was an accepted practice with respect to former clients, and less experienced judges were as likely as their more senior colleagues to express the minority view that there is an accepted cooling-off period with respect to hearing cases in which the judge's former law firm appears as counsel. ${ }^{51}$

Twenty-one of our respondents from Nova Scotia answered questions C1 (cooling-off period for a judge's former firm) and C2 (cooling-off period for a judge's former clients). In response to C1, 18 of the judges indicated that there was no accepted cooling-off period for hearing cases involving the judge's former law firm, whereas three judges thought there was such a cooling-off period. Of the three judges who thought that there was a cooling-off period, one had been on the bench for five years or less, one had served between six and ten years as a judge, and one had been a judge for more than ten years. Twenty of the 21 judges agreed that there was no accepted cooling-off period for judges hearing cases involving former clients (C2). This included all six of the judges who had served for less than five years, and the one judge who had a different view had served for more than ten years. Among the Ontario respondents, 33 answered $\mathrm{C} 1$ and 32 answered C2. Twenty-two respondents answered C1 by indicating that there was no accepted cooling-off period for hearing cases from the judge's former law firm, and 11 thought there was such a cooling-off period. Two of the eight respondents who had been judges for less than five years thought that there was an accepted cooling-off period; four of the seven judges who served for between six and ten years thought that there was an accepted cooling-off period; and five of the 16 judges who had been on the bench for more than ten years reported that there was an accepted 
Overall, it seems to us that lack of knowledge of the prevailing view of judicial colleagues may be at least part of the explanation for different responses to at least some scenarios. This explanation seems particularly persuasive in respect of the roughly one-third of the scenarios in which there is clearly a dominant opinion expressed by our respondents. It may be the case, of course, that some judges would respectfully disagree with the views of the large majority of their colleagues on how to address some scenarios. Nevertheless, it seems plausible to us that many of the judges who expressed a minority view in the scenarios in which there is a strong majority opinion would change their minds if they were aware that most of their colleagues took a different view of the situation.

\section{DisCOMFORT WITH AdJUdicATING WHERE THE JUdGE IS NOT WANTED}

The final explanation we thought worthwhile to explore was the possibility that judges experience different levels of discomfort with adjudicating in a situation in which one party has genuine concerns about the perception of judicial impartiality, even if those concerns would not be shared by reasonable people. In Wewaykum, the Supreme Court of Canada acknowledged that there might be situations in which judges recuse themselves out of an abundance of caution even though, strictly speaking, the law does not require that they do so. $^{52}$

There can be two reasons for judges to act in this manner. One is that some judges may be philosophically predisposed to believe that where a litigant harbours a doubt about the judge's impartiality, it does not serve the interests of justice to force that litigant to have his or her case adjudicated by that particular judge. For judges who take this view, even though the reasonable apprehension of bias test is an objective one, at least in the ordinary case it simply makes sense for a judge to recuse himself or herself if one of the litigants has a subjective concern about the judge's impartiality. That point of view can be contrasted to what is sometimes referred to as the "duty to sit" doctrine. ${ }^{53}$ Judges who support the duty to

cooling-off period. Twenty-seven of the 32 judges who answered C2 indicated that there was no accepted cooling-off period for a judge to hear cases involving a former client, whereas five judges thought that there was an accepted cooling-off period in this situation. Of the five judges who thought that there was an accepted cooling-off period, none were in the first five years of their judicial career; two had been on the bench for between six and ten years, and three had served for more than ten years. Supra note 3 at para. 78 :

[I]n circumstances such as the present one, where the issue of disqualification arises after judgment

has been rendered, rather than at an earlier time in the proceedings, it is neither helpful nor necessary to determine whether the judge would have recused himself or herself if the matter had come to light earlier. There is no doubt that the standard remains the same, whenever the issue of disqualification is raised. But hypotheses about how judges react where the issue of recusal is raised early cannot be severed from the abundance of caution that guides many, if not most, judges at this early stage. This caution yields results that may or may not be dictated by the detached application of the standard of reasonable apprehension of bias. In this respect, it may well be that judges have recused themselves in cases where it was, strictly speaking, not legally necessary to do so. Put another way, the fact that a judge would have recused himself or herself ex ante cannot

be taken to be determinative of a reasonable apprehension of bias ex post.

53 This doctrine appears in the judicial disqualification jurisprudence of a number of countries. In the United States, it has been referred to with approval in the Supreme Court by Rehnquist C.J. in Laird v. Tatum, 409 U.S. 824 at 837 (1972), and applied by Scalia J. in Cheney v. U.S. District Court for the District of Columbia, 541 U.S. 913 at 916, 926-27 (2004). The doctrine has been endorsed by the South African Constitutional Court in S.A.R.F.U., supra note 22 at para. 48, and the High Court of Australia in Re J.R.L., [1986] HCA 39, 161 C.L.R. 342 at para. 6 [J.R.L.]. Canadian cases making reference to the duty to sit include Rando Drugs Ltd. v. Scott, 2007 ONCA 553, 86 O.R. (3d) 641 at para. 19 (referring to the S.A.R.F.U. case); Kalo v. Manitoba (Human Rights Commission), 2008 MBQB 92, 226 Man. R. (2d) 139 at para. 23; R. v. Kochan, 2001 ABQB 346, 288 A.R. 333 at para. 33; Broda v. Broda, 2000 ABQB 948, 285 A.R. 201 at para. 28 (both referring to the J.R.L. decision). 
sit doctrine believe that it is inappropriate, and perhaps even a dereliction of their duty, if they step down in cases in which they are not obliged to do so as a strict matter of law.

The other reason that some judges might be inclined to recuse themselves in marginal cases is a prudential one. The consequences for both the litigants and the judge of an incorrect determination that it is acceptable for the judge to sit in a marginal case are particularly unpleasant. Of course, it is inevitable that judges must make legal rulings in marginal situations, and those determinations are inevitably vulnerable to being overturned on appeal. One of the unfortunate consequences of the tendency of some courts to explain the results of their analysis of the reasonable apprehension of bias test by referring to the presumed knowledge or attitudes of the reasonable person is that those who do not agree with this analysis tend to be stigmatized as unreasonable. In cases where there is a risk that a decision will be overturned on account of a reasonable apprehension of bias, therefore, it is not surprising that some judges will want to err on the side of caution to avoid a situation that might have this unhappy result.

Insert Chart 10

In order to identify the extent to which individual judges exhibited a greater or lesser sensitivity to the likeliness that recusal would be appropriate, we plotted the number of times each participant answered that he or she would definitely recuse, recuse if a party objects, or definitely not recuse in the 32 scenarios. As the histograms demonstrate, some judges are 
much more likely than others to consistently answer that they would definitely recuse themselves, definitely not recuse themselves, or recuse if a party objects. ${ }^{54}$

As is evident from the histogram below, a handful of our respondents never indicated that they would definitely recuse themselves if faced by one of our scenarios or gave that answer in three or fewer scenarios. ${ }^{55}$ The bulk of the respondents clustered either in a "moderately reluctant to recuse" group, indicating that they would definitely recuse themselves between four and nine times ${ }^{56}$ or in a "moderately likely to recuse group" that answered that they would definitely recuse themselves between ten and 15 times. ${ }^{57}$ The remaining 8 percent indicated that they would definitely recuse themselves between 17 and 22 times.

\section{Insert Chart 11}

The pattern of distribution of answers that the respondent would recuse if a party objects was somewhat more smooth than the distribution of responses that the respondent would definitely recuse himself or herself, but a small number of respondents gave this response to more than two-thirds of the scenarios. Thirty percent of the respondents gave this answer

We also plotted the number of times individual judges indicated that they were uncertain. More than a third of the respondents never indicated that they were uncertain, and another third answered that they were uncertain fewer than five times. No respondent indicated that they were uncertain more than 13 times. The histograms do not reflect situations in which the respondent was uncertain or did not answer the question, but given the relative infrequency of these responses we do not believe that this interferes with the overall value of our observations.

55 Eleven percent of respondents indicated that they would definitely recuse themselves three or fewer times.

$56 \quad$ Forty percent of respondents were in this group.

$57 \quad$ This group made up 42 percent of the respondents. 
between zero and five times, 32 percent gave this answer between six and ten times, and another 34 percent responded that they would recuse themselves if a party objected between 11 and 18 times. The remaining 4 percent answered that they would recuse themselves if a party objected more than 20 times, with the highest rate of response being 28 times on a questionnaire that had 32 scenarios.

Insert Chart 12

The response that the participant definitely would not recuse himself or herself was also reasonably evenly distributed, though there was some clustering of judges who were very unlikely to indicate that they would definitely refuse to recuse themselves, and another cluster that was considerably more likely to take this view than their colleagues. Thirty-four percent of respondents indicated that they would definitely not recuse themselves between zero and five times. Another 35 percent answered that they would definitely not recuse themselves between six and ten times. Another 20 percent stated that they would definitely not recuse themselves between 11 and 15 times, and the remaining 10 percent gave this answer between 16 and 22 times.

We also thought that it would be useful to plot the number of times respondents gave either the answer that they would definitely recuse themselves, or that they would do so if a party objects. The following histogram provides a composite picture of the relative predisposition of respondents to recuse rather than definitely not do so. 
Insert Chart 13

Once again, it is evident that there is a wide divergence of opinion among the participants in our study. Ten percent of respondents answered that they would either definitely recuse themselves or recuse themselves if a party objected fewer than ten times, with the lowest number being four times. At the other end of the spectrum of opinion, 12 percent of respondents indicated a leaning toward recusal between 26 and 31 times. The group that was moderately reluctant to recuse (those who indicated a leaning toward recusal between ten and 15 times) made up 24 percent of participants, and another 24 percent could be classified as moderately likely to recuse, indicating that they would definitely recuse themselves or recuse if a party objects between 20 and 25 times.

In light of this information, it seems difficult to avoid the conclusion that a judge's personal philosophy with respect to the appropriateness of recusal plays an important role in that individual's decision whether to recuse himself or herself in marginal cases. This does not mean that recusal decisions in marginal cases are entirely subjective. As we showed above, in a number of the scenarios we identified that there was clearly a dominant view among our respondents about the proper approach to take, and in another group of scenarios there was a clear majority that favoured a particular response. On the other hand, it seems to us that those judges who take what might be described as “outlier” positions with respect to certain scenarios are particularly likely to be influenced by their personal judicial philosophy in making choices that do not seem to be consistent with the dominant view. Likewise, in scenarios in which there was a particularly wide divergence of opinion, it seems likely that a judge's personal philosophy with respect to recusal would often play an important role in determining which option the judge would choose. 


\section{CONCLUSION}

Our findings demonstrate that there is a wide divergence of opinion among respondents in their attitudes toward recusal in a number of reasonably common marginal scenarios. We identified a number of factors that seem to have some influence on the responses of judges to some scenarios, though the role of these factors appears to be more significant in some situations than in others. How Canadian judges should respond to this evidence will have to be the subject of another article on our part, though it seems evident to us that there is no single approach that is likely to produce dramatic improvements in the overall level of consistency in marginal cases. Among the approaches that seem promising to us to explore are a more explicit consideration in the jurisprudence of the role played by the effective administration of justice in determinations with respect to recusal, clearer communication of common practices and expectations, whether through the promulgations of rules or through judicial education, and a more explicit discussion of the differences in judicial philosophy that seem to underlie at least part of this divergence of opinion. We hope that our study has shed some light on judicial experience in an area that is very important to litigants and judges, but in which reported decisions do not give a complete picture of that experience. We hope that our work will stimulate further discussion and debate in arenas in which judges, lawyers, and others attempt to understand and improve upon the workings of our system of justice. 


\section{APPENDIX: \\ SURVEY OF CANAdiAN PROVINCIAL AND TERRITORIAL JUDGES CONCERNING JUDICIAL RECUSAL}

\section{Questions Concerning Recusal Scenarios}

In answering the following questions, assume that you are sitting in the location in which you sit for the majority of your cases. Likewise assume that there are no special circumstances that would make other judges more or less available to replace you if you do recuse yourself, or cause delays over and above those that you would normally anticipate as the result of your recusal.

\section{Professional Relationships}

1. Assume that prior to your judicial appointment you had been opposing counsel to a lawyer in a number of trials. Assume as well that on some occasions acrimonious exchanges took place between you and the lawyer. After one of these exchanges the lawyer made a complaint about you to the Law Society. Although the complaint was eventually dismissed, responding to it put you to some effort and was very unpleasant. This lawyer now appears before you representing a person accused of sexual assault. The lawyer has not asked you to recuse yourself, but you have some concern about the possibility that your past antagonism as counsel will colour the conduct of the trial.

2. Assume that prior to your judicial appointment you had been opposing counsel to a lawyer in a number of trials. Assume as well that on one occasion you believed that the lawyer behaved in an unprofessional manner and you reported the lawyer to the Law Society. The result of this complaint was that the lawyer was reprimanded by the Law Society. This lawyer now appears before you representing a person accused of sexual assault and asks you to recuse yourself.

3. You are assigned to hear a child protection matter in which counsel for the mother is a partner in a five person law firm. Within the past year, one of the lawyer's partners acted for you successfully in a claim against a builder for negligent construction of a renovation to your house.

4. You are assigned to hear a small claims matter in which you are well acquainted with counsel for the plaintiff. You did not practice with this lawyer but you worked together on a number of Law Society and Canadian Bar Association committees. You often take part in the same charity golf tournaments and it is not unusual for you to be part of the same foursome at these events.

5. You are assigned to hear a sexual assault trial in which you are well acquainted with Crown counsel. You did not practice with this lawyer but you worked together on a number of Law Society and Canadian Bar Association committees. You often take part in the same charity golf tournaments and it is not unusual for you to be part of the same foursome at these events. 


\section{E. Social Relationships}

1. At the commencement of a small claims trial you realize that the defendant is an individual whom you know socially. You would not describe this individual as a friend, but you have met each other at more than one social gathering and consider yourself to be on a first name basis. You have no knowledge of the facts of the lawsuit itself.

2. At the commencement of a criminal trial for impaired driving you realize that the accused is an individual whom you know socially. You would not describe this individual as a friend, but you have met each other at more than one social gathering and consider yourself to be on a first name basis. You have no knowledge of the facts of the case itself.

3. At the commencement of a criminal trial for breaking and entering you realize that the homeowner whose house was allegedly broken into is someone you know socially. You would not describe this individual as a friend, but you have met each other at more than one social gathering and consider yourself to be on a first name basis. You have no knowledge of the facts of the case itself, and you have no reason to believe that the homeowner will be called as a witness.

4. You are scheduled to hear a small claims trial in which the plaintiff is the owner of a grocery store at which you frequently shop. You often exchange pleasantries with the owner of the store when you are shopping there but you have no acquaintanceship in any other setting. The claim is that the defendant, who is unknown to you, purchased goods on credit and subsequently did not pay the bill.

5. Partway through a small claims trial you realize that the plaintiff's key witness is a close personal friend. You have known each other since you went to university together and you go out to dinner together several times a year. There is a significant likelihood that the outcome of the case will turn on your findings concerning the accuracy of this witness's recollection of the relevant events. Your friend has not talked to you about the case and prior to coming into court you had no knowledge of the facts of the case.

6. Partway through a small claims trial you realize that the plaintiff's key witness is a close personal friend of one of your children. This individual has been to your home on numerous occasions, but the individual's friendship is with your child rather than with you personally. There is a significant likelihood that the outcome of the case will turn on your findings concerning the accuracy of this witness's recollection of the relevant events. The witness has not talked to you about the case outside of court and prior to coming into court you had no knowledge of the facts of the case. 


\section{F. Knowledge Derived from Other Judicial Proceedings}

\section{Bail Hearings}

In scenarios F1-F5 below, assume that you conducted a bail hearing.

1. You granted judicial interim release. You are now scheduled to conduct the trial.

2. You remanded the accused into custody because he had no fixed address. You are now scheduled to conduct the trial.

3. During the bail hearing, the accused testified. You made an adverse credibility finding and remanded the accused. You are now scheduled to conduct the trial.

4. During the bail hearing, you were provided with information about the accused's character, antecedents and criminal record and with information about the offence. You are now scheduled to conduct the trial.

5. In scenarios F1-F4, would it make a difference if more than 6 months had passed between the bail hearing and the beginning of the trial?

\section{Subsequent/Multiple Trials}

6. Eighteen months ago you presided over a criminal trial. You found the accused guilty and sentenced the accused to six months imprisonment. The same person now stands accused before you on an unrelated criminal charge.

7. An accused you previously convicted and sentenced is being tried on a new, unrelated charge and has been remanded into custody. A recusal would likely involve some delay. The accused is not expected to take the stand. You are scheduled to conduct the trial.

8. An accused you previously convicted and sentenced is being tried on a new, unrelated charge and has been remanded into custody. A recusal would likely involve some delay. The accused is expected to take the stand. You are scheduled to conduct the trial.

9. A person whom you have previously convicted and sentenced is the principal witness for the defence in the trial of another person. You determined that his testimony at his own trial was not credible. You are scheduled to conduct the trial.

10. There are two separate informations, one against $A$ for assault on $B$, the other against $B$ for uttering a threat against $A$. Both incidents allegedly occurred on the same day. You are scheduled to conduct both trials. 
11. Assume that you tried and convicted A. During the course of sentencing A you heard representations concerning threats B allegedly made against A. You are scheduled to conduct B's trial.

12. You made an order for support for a spouse. You are now scheduled to hear a spousal assault case involving the same parties.

13. You remanded the accused into custody on a charge relating to his child. You are now scheduled to preside over a child protection matter concerning the alleged child victim.

14. You have sentenced the accused on five prior occasions in the last four years. All offences were property-related. You are now scheduled to conduct the trial on a receiving stolen property charge.

\section{Subsequent Related Proceedings}

15. You remanded the accused into custody; you are now scheduled to conduct the preliminary inquiry.

16. You presided over a preliminary inquiry for which the accused had elected Judge and Jury. The accused then re-elects to provincial court and intends to plead guilty. You are scheduled to sentence the accused.

17. You convicted the accused of assault. You ordered a conditional sentence with a condition of abstention from alcohol. The accused is allegedly in breach of the conditional order. You are scheduled to hear the breach hearing.

18. You remanded an accused into custody for a breach hearing. You are scheduled to hear the breach hearing.

19. You heard a dangerous offender application. You found the accused to be a dangerous offender. Your decision was overturned on appeal. You are scheduled to sit on a subsequent long-term offender application involving the same individual.

20. You issued a search warrant based on extensive affidavit evidence, much of which would be inadmissible at trial. The search yielded evidence and you are now scheduled to conduct the trial.

21. In a civil matter you are involved in court-annexed mediation. There is no settlement. The mediation rules do not guarantee parties that if their case is not settled it will be heard by a different judge than the one who took part in the mediation. You are now scheduled to hear the trial.

22. You heard a small claims trial. You are scheduled to hear a subsequent trial between the same parties where the defendant pleads estoppel by virtue of the outcome of the first trial. 
this page is blank - do not strip it in 